Short Report on an Intensive Archeological Survey for the SchertzSeguin Local Government Corporation's Proposed SH123/Austin Street Water Line Installation Project, Guadalupe County, Texas

Steven Sarich

Josh Haefner

Hicks \& Company

Follow this and additional works at: https://scholarworks.sfasu.edu/ita

Part of the American Material Culture Commons, Archaeological Anthropology Commons, Environmental Studies Commons, Other American Studies Commons, Other Arts and Humanities Commons, Other History of Art, Architecture, and Archaeology Commons, and the United States History Commons

Tell us how this article helped you.

This Article is brought to you for free and open access by the Center for Regional Heritage Research at SFA ScholarWorks. It has been accepted for inclusion in Index of Texas Archaeology: Open Access Gray Literature from the Lone Star State by an authorized editor of SFA ScholarWorks. For more information, please contact cdsscholarworks@sfasu.edu. 


\section{Short Report on an Intensive Archeological Survey for the Schertz-Seguin Local Government Corporation's Proposed SH123/Austin Street Water Line Installation Project, Guadalupe County, Texas}

Creative Commons License

(c) (i) (9)

This work is licensed under a Creative Commons Attribution-NonCommercial 4.0 International License 


\section{SHORT REPORT ON AN INTENSIVE ARCHEOLOGICAL SURVEY FOR THE SCHERTZ-SEGUIN LOCAL GOVERNMENT CORPORATION'S PROPOSED SH123/AUSTIN STREET WATER LINE INSTALLATION PROJECT, GUADALUPE COUNTY, TEXAS}

By:

Steven Sarich and Josh Haefner

Prepared for:

Schertz-Seguin Local Government Corporation

Prepared by:

TRC Environmental Corporation

505 East Huntland Drive, Suite 250

Austin, Texas 78752

Texas Antiquities Permit No. 9263

Josh Haefner, Principal Investigator

TRC Technical Report No. 366016.0000

April 2020 

Short Report on an Intensive Archeological Survey for the Schertz-Seguin Local Government Corporation's Proposed SH123/Austin Street Water Line Installation Project, Guadalupe County, Texas

This page intentionally left blank 


\section{MANAGEMENT SUMMARY}

Schertz-Seguin Local Government Corporation (Client) is proposing to construct an 18-inch water main pipeline along the west side of State Highway (SH) Business 123 (Stockdale Highway/South Austin Street) crossing of the Guadalupe River in the City of Seguin, Guadalupe County, Texas (Project). According to current design plans, the proposed water line would be connected to an existing pipeline located approximately 75 feet (ft) [23 meters (m)] north of the Guadalupe River near the existing Max Starke Park Water Treatment Plant and an existing main pipeline located approximately $75 \mathrm{ft}(23 \mathrm{~m})$ south of the Guadalupe River along SH 123 in Seguin, Texas. The Area of Potential Effects (APE) consists of two work areas, one north and one south of the Guadalupe River. The northern work area consists of 0.20 acres (ac) and the southern work area consists of 0.15 ac. The APE is $0.35 \mathrm{ac}$ in total. The Project is within the City of Seguin, a subdivision of the state, and thus triggers a review of cultural resources under the Antiquities Code of Texas (Section 191.0525). Additionally, due to Army Corps of Engineers (USACE) permitting requirements the Project falls under the regulations of Section 106 of the National Historic Preservation Act of 1966, as amended (U.S. Code 16, §470, et seq.).

TRC archeologists conducted a limited desktop literature and archives review for the proposed Project to assess whether previously recorded cultural resources are within or adjacent to the APE or within a 1-mile (mi) (1.6-kilometer $[\mathrm{km}]$ ) of the APE. This included a review of the THC's Archeological and Historic Sites Atlas (Atlas) which provides information related to the location of previously conducted archeological surveys and recorded archeological sites, cemeteries, properties currently listed or eligible for listing on the National Register of Historic Places (NRHP), Recorded Texas Historic Landmarks (RTHLs), and State Antiquities Landmarks (SALs) that may be impacted by the proposed Project. According to the THC-Atlas, no previously conducted archeological surveys, archeological sites, cemeteries, historic properties, or historical markers intersect or are adjacent to the APE.

Fieldwork was conducted by TRC archeologists on February 12, 2020 under Antiquities Permit Number 9263. The intensive archeological field survey included survey of 100 percent of the APE supplemented with shovel testing and visual inspection. Survey methods followed the guidelines and survey standards set forth by the THC and Council of Texas Archeologists (CTA). Review of the project plans showed that of the $155 \mathrm{~m}(509 \mathrm{ft})$ proposed water line only $27 \mathrm{~m}(89 \mathrm{ft})$ of the line to the north and $18 \mathrm{~m}(59 \mathrm{ft})$ of the line to the south will be buried with the remainder above ground and spanning the Austin Street bridge. Survey efforts were concentrated along the buried portions of the proposed water line. Due to the high degree of ground disturbance from existing utilities, bridge construction, and the presence of steep slope only a single shovel test could be excavated. Nine additional 'No Dig' observation points were recorded to document the areas of disturbance and slope. No cultural resources or historic structures were identified within the APE. No additional work is recommended. 
Short Report on an Intensive Archeological Survey for the Schertz-Seguin Local Government Corporation's Proposed SH123/Austin Street Water Line Installation Project, Guadalupe County, Texas

This page intentionally left blank. 


\section{TABLE OF CONTENTS}

$\underline{\text { Section }}$

$\underline{\text { Page }}$

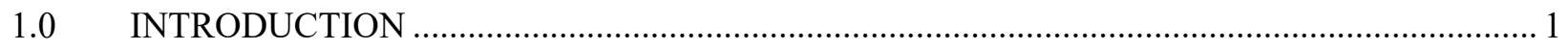

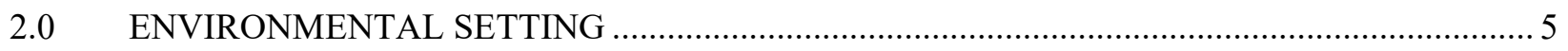

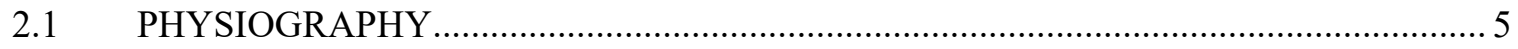

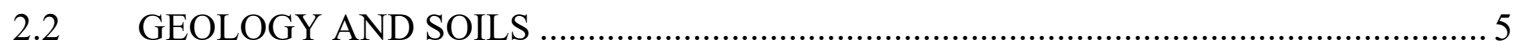

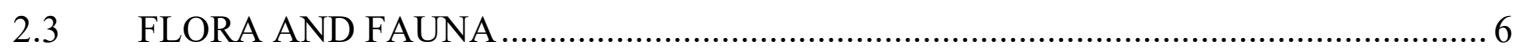

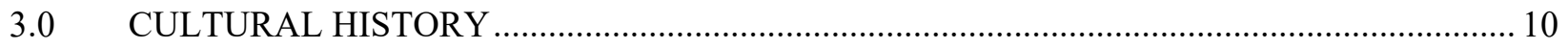

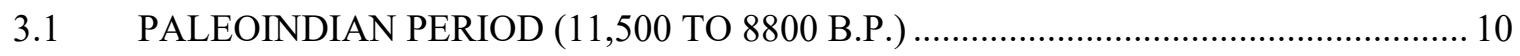

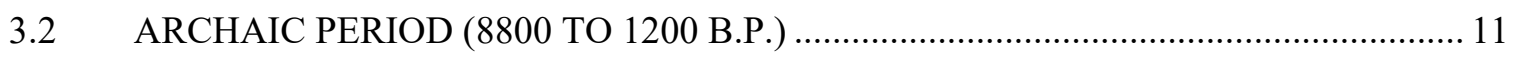

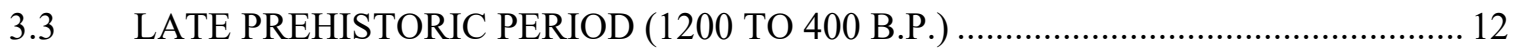

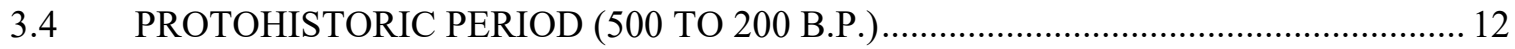

3.5 HISTORIC PERIOD (200 B.P. TO 50 B.P.) ........................................................... 13

4.0 PREVIOUS INVESTIGATIONS AND PREVIOUSLY RECORDED CULTURAL

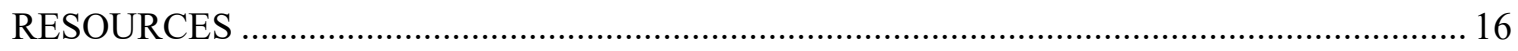

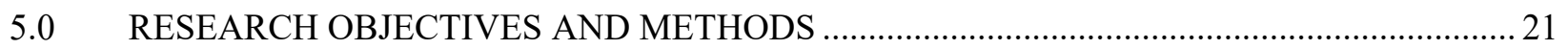

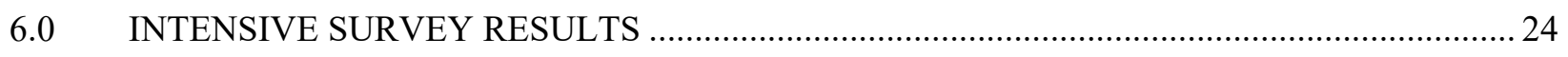

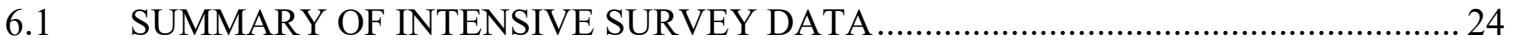

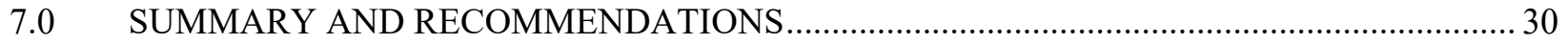

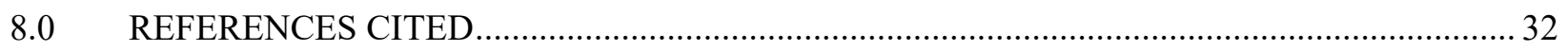




\section{LIST OF FIGURES}

Figure 1-1 Proposed SH123 water line APE plotted on Seguin 7.5' topographic quadrangle...........................2

Figure 1-2 Proposed SH123 water line APE plotted on 2019 Google Earth aerial imagery. ............................ 3

Figure 2-1 Underlying geology of the APE according to the Geologic Atlas of Texas Seguin Sheet...............7

Figure 2-2 Predominant soils of the APE according to the USDA/NRCS Web Soil Survey.............................

Figure 4-1 Previously recorded cultural resources and surveys within 1-mile of the APE. .............................17

Figure 5-1 Detailed view of the APE with buried (yellow) and above ground (green) water line piping. .......22

Figure 6-1 Shovel test results map on USGS Seguin 7.5' topographic quadrangle......................................25

Figure 6-2 Shovel test results map on aerial imagery ............................................................................26

Figure 6-3 Overviews at area conditions and water facility surrounding shovel test 1-SS, facing south

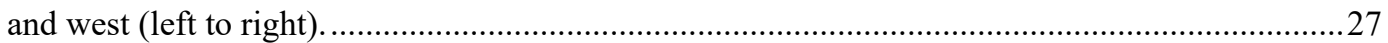

Figure 6-4 Shovel test profile for 1-SS showing gravel and mottled soil conditions, facing south................27

Figure 6-5 Overviews of the existing water line and existing gas line in the northern portion of the APE,

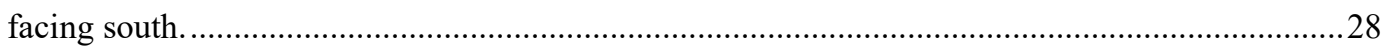

Figure 6-6 Overviews of the ground disturbance from bridge construction and steep slope to river, facing east and west (left to right)............................................................................................ 28

Figure 6-7 Overviews of the southern portion of the APE showing steep slope adjacent to bridge abutment, facing north and east (left to right)

Figure 6-8 Overview of the southern portion of the APE showing the existing gas line and water line, facing east.

\section{LIST OF TABLES}

Table 1. Previous archeological surveys within 1-mile of the APE (THC 2020)..................................................18

Table 2. Cultural resources identified within 1-mile of the APE (THC 2020) .....................................................18

Table 3. Historical markers located within 1-mile of the APE (THC 2020) ......................................................19

\section{LIST OF APPENDICES}

Appendix A - Project Plans

Appendix B - Shovel Test Log 



\subsection{INTRODUCTION}

In February 2020, under contract with the Schertz-Seguin Local Government Corporation (Client), TRC Environmental Corporation (TRC) conducted an intensive archeological survey for the proposed SH123/Austin Street Water Line Installation Project (the Project) located in Guadalupe County, Texas (Figures 1-1 and 1-2). As the Project is within the City of Seguin, an entity of the state of Texas, a survey of cultural resources is necessary to meet the requirements as outlined in the Antiquities Code of Texas (Section 191.0525). Additionally, due to Army Corps of Engineers (USACE) permitting requirements the Project falls under the regulations of Section 106 of the National Historic Preservation Act of 1966, as amended (U.S. Code 16, §470, et seq.).

According to current design plans, the proposed water line would be connected to an existing pipeline located approximately 75 feet (ft) [23 meters (m)] north of the Guadalupe River near the existing Max Starke Park Water Treatment Plant and an existing main pipeline located approximately $75 \mathrm{ft}(23 \mathrm{~m})$ south of the Guadalupe River along SH 123 in Seguin, Texas. The Area of Potential Effects (APE) consists of two work areas, one north and one south of the Guadalupe River. The northern work area consists of 0.20 acres (ac) and the southern work area consists of $0.15 \mathrm{ac}$. The APE is $0.35 \mathrm{ac}$ in total. The anticipated maximum depth of impacts for the entire project is $10 \mathrm{ft}$ with much of the proposed line to be installed above ground (Appendix A). The archeological survey determined whether cultural resources or historic standing structures are located within the APE of the proposed project and, if so, assess the significance and eligibility for their designation as a State Antiquities Landmark (SAL) and for inclusion in the National Register of Historic Places (NRHP).

Fieldwork was conducted by TRC archeologists on February 12, 2020 under Antiquities Permit Number 9263. The intensive archeological field survey included survey of 100 percent of the APE supplemented with shovel testing and visual inspection. Survey methods followed the guidelines and survey standards set forth by the Council of Texas Archeologists (CTA). Review of the project plans showed that of the $155 \mathrm{~m}$ $(509 \mathrm{ft})$ proposed water line only $27 \mathrm{~m}(89 \mathrm{ft})$ of the line to the north and $18 \mathrm{~m}(59 \mathrm{ft})$ of the line to the south will be buried with the remainder above ground and spanning the Austin Street bridge. Survey efforts were concentrated along the buried portions of the proposed water line. Due to the high degree of ground disturbance from existing utilities, bridge construction, and the presence of steep slope only a single shovel test could be excavated. Nine additional 'No Dig' observation points were recorded to document the areas of disturbance and slope. No cultural resources or historic structures were identified within the APE. No additional work is recommended. 


\section{CUI/PRIV -- CONTAINS PRIVILEGED INFORMATION - DO NOT RELEASE}

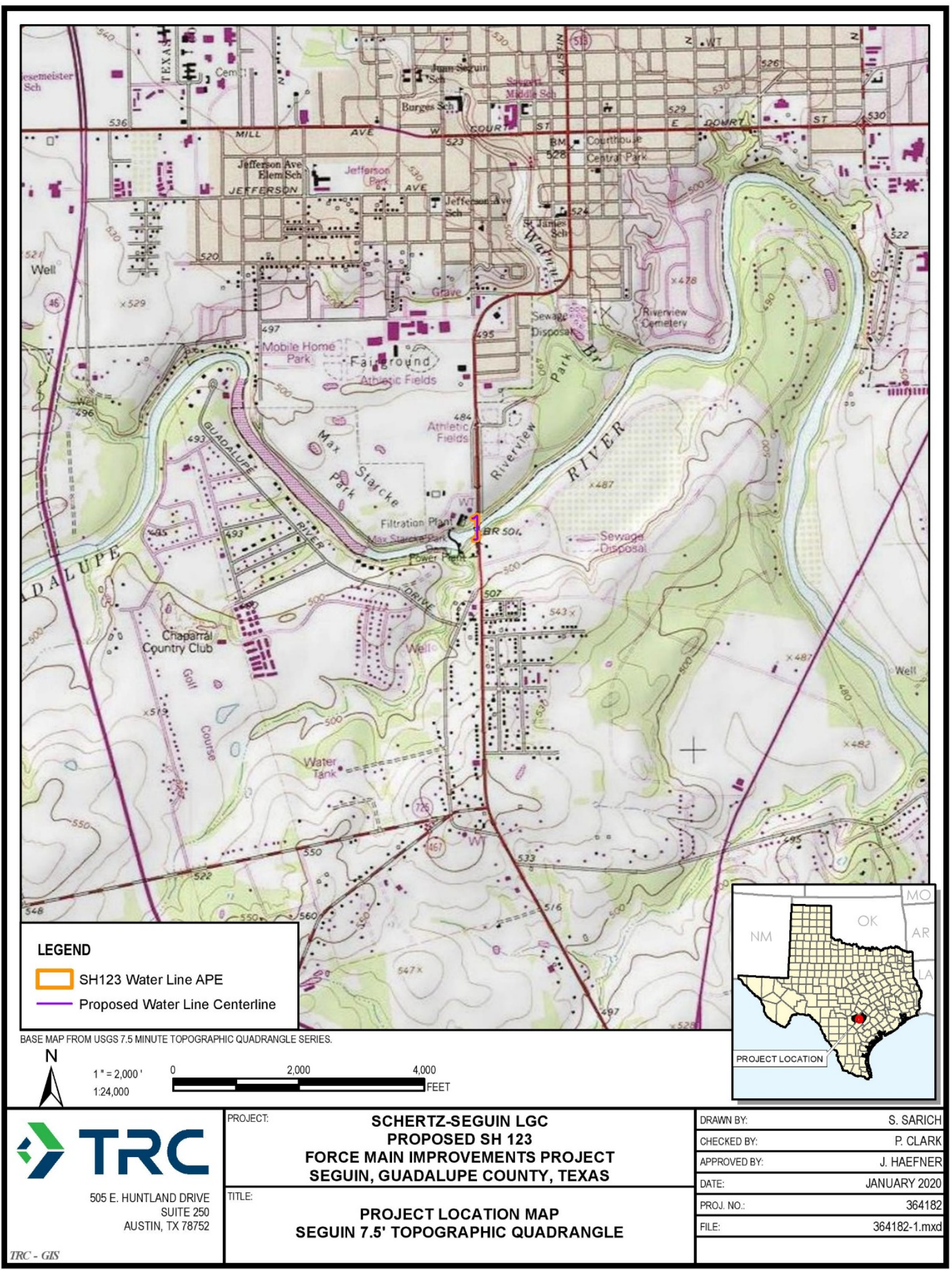

Figure 1-1 Proposed SH123 water line APE plotted on USGS Seguin 7.5' topographic quadrangle. 
Short Report on an Intensive Archeological Survey for the Schertz-Seguin Local Government Corporation's Proposed SH123/Austin Street Water Line Installation Project, Guadalupe County, Texas

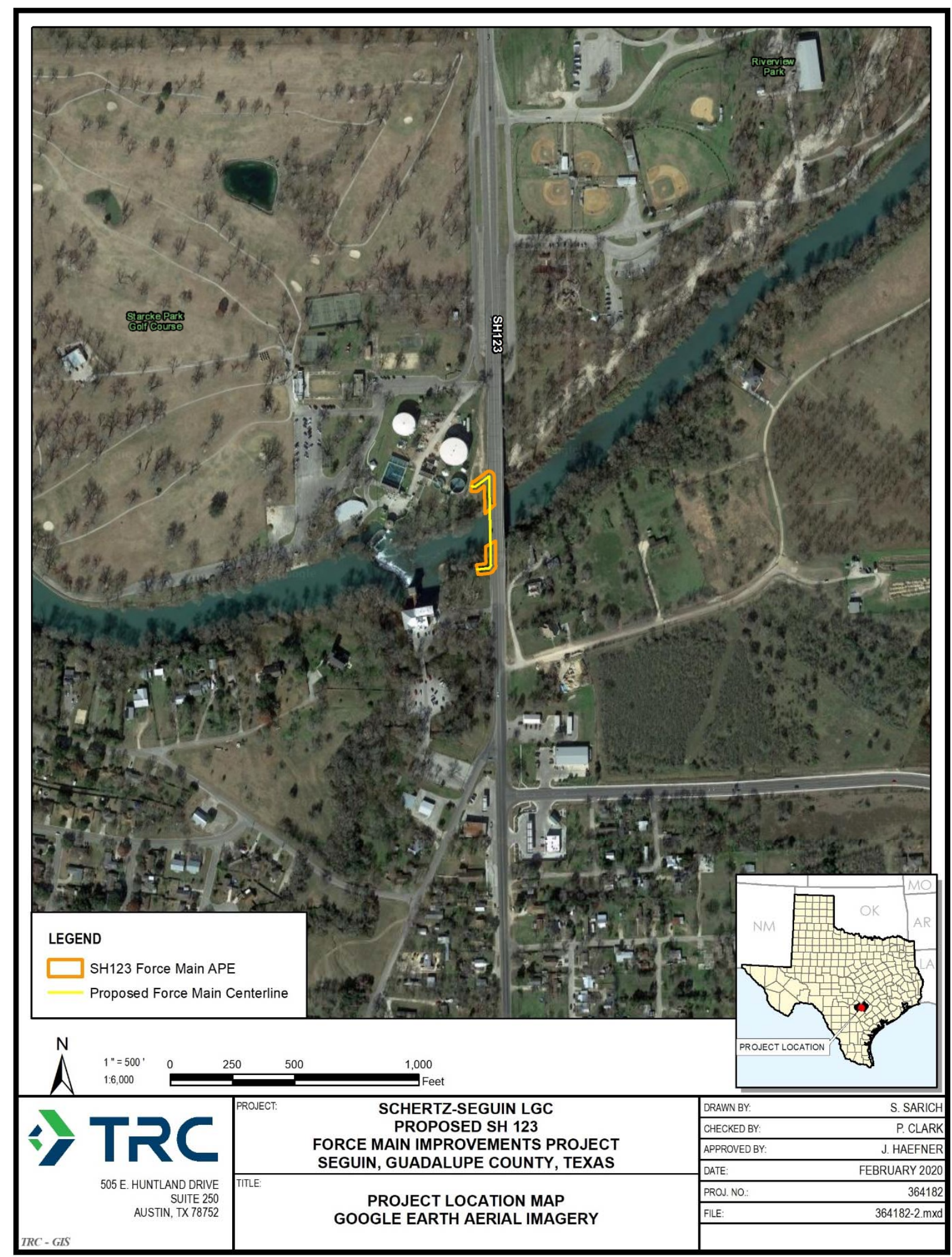

Figure 1-2 Proposed SH123 water line APE plotted on 2019 Google Earth aerial imagery. 
This page intentionally left blank. 


\subsection{ENVIRONMENTAL SETTING}

\subsection{PHYSIOGRAPHY}

The City of Seguin (City) lies some 15 miles (mi) (24 kilometers [km]) east of the Balcones Escarpment and $36 \mathrm{mi} .(58 \mathrm{~km})$ northeast of San Antonio in the Blackland Prairie. The escarpment is formed from a fault system and creates a sharp visual and topographical break in the landscape. The APE is in the narrow southern end of the Blackland Prairie, a relatively flat ecological region that generally parallels the Balcones Escarpment and extends from central Texas northward to the Red River. This zone was characterized by grasslands with scattered trees (Griffith et al. 2007). A short distance further east is the Inner Gulf Coastal Plain that stretches to the Gulf of Mexico. Walnut Branch is a short intermittent tributary that flows south into Guadalupe River just south of the City. The Guadalupe River originates in the Edwards Plateau and flows southeastward across the Blackland Prairie and joins the San Marcos River farther east, eventually flowing into the Gulf of Mexico.

Historically, the land use across much of the Blackland Prairie was dominated by intensive agriculture (Griffith et al. 2007). This followed land clearing activities that undoubtedly removed much of the woodlands along and throughout the Blackland Prairies. Currently, riparian woodlands exist primarily along the margins of the Guadalupe River and other watered environments outside the developed areas.

\subsection{GEOLOGY AND SOILS}

According to the Geologic Atlas of Texas (Seguin Sheet), the predominant geology of the APE is mapped as Alluvium (Qal) of Holocene age. Alluvium consists of low terrace deposits along streams comprised of sand, silt, clay, and gravel with a variable thickness (Figure 2-1).

The soils within the APE are mapped as Seguin silty clay loam (Se) and frequently flooded Uhland soils (Uw) according to the United States Department of Agriculture Natural Resources Conservation Service Web Soil Survey. Barbarosa silty clay (BaA) is immediately adjacent to the APE (Figure 2-2). A brief description of each series is provided below:

- Seguin silty clay loam, flooded (Se) is characterized by loamy alluvium of Holocene age derived from mixed sources and located on flood plains. A typical profile includes 0 to 158 centimeters $(\mathrm{cm})$ of silty clay loam.

- Uhland soils that are frequently flooded (Uw) are characterized by loamy alluvium of Holocene age derived from mixed sources and located on flood plains. A typical profile includes 0 to $18 \mathrm{~cm}$ of clay loam, 18 to $158 \mathrm{~cm}$ of fine sandy loam, and 158 to $203 \mathrm{~cm}$ of loam.

- Barbarosa silty clay (BaA) with 0 to 1 percent slopes is characterized by clayey alluvium derived from mixed sources and is located on stream terraces. A typical profile includes 0 to $122 \mathrm{~cm}$ of silty clay and 122 to $183 \mathrm{~cm}$ of clay.

Given the characteristics of the overlying soils and the characteristics of the underlying Holocene age geology, the APE has the potential to contain intact deeply buried prehistoric cultural materials, as well as surficial and shallow subsurface artifacts. 


\subsection{FLORA AND FAUNA}

Tharp (1939) designates this area as an extension of the bluestems-(Andropogon)-Stipa-three-awns (Aristida) association of the Tall Grass Prairie. Presently, the bottomlands (floodplains) have been significantly altered from their original state and are comprised of ground-cover regrowth understory (Kenmotsu 1982; Griffith et al. 2007). These areas are now dominated by introduced species such as brome grasses, rescuegrass (Bromus unioloides) and Japanese brome (Bromus japonicas). Canadian wildrye (Elymus canadensis) and Johnson grass (Sorghum halepense) are found in shaded areas by midsummer, along with scattered populations of Texas Wintergrass (Stipa leucotricha). The overstory includes: netleaf hackberry (Celtis reticulate), cedar elm (Ulmus crassifolia), pecan (Carya sp.), red ash (Fraxinus pensylvanica), red mulberry (Morus rubra), eastern cottonwood (Populus deltoids), prickly ash (Xanthoxylum clava- herculis), deciduous holly (Ilex decidua), black willow (Salix nigra), osage orange (Maclura pomifera), box elder (Acer negundo), soapberry (Sapindus saponaria), and chinaberry (Melia azearach) (Griffith et al. 2007; Kenmotsu 1982:3-15).

The upland prairie assemblages also reflect disturbed conditions with Johnson grass (Sorghum halepense), Roosevelt weed (Baccharis neglecta), hedge parsley (Torilis arvensis), yellow sweet clover (Melilotus officinalis), and silver-leaf nightshade (Solanum elaeagnifolium). Other major species in the area include prairie three-awn (Aristida oligantha) and little bluestem (Schizachyrium scoparium) (Griffith et al. 2007; Kenmotsu 1982).

Although most discussions of the Blackland Prairie do not provide potential plant food resources, botanists such as Dering (2000) have offered up a number of potential geophyte resources in the Blackland Prairie region that might have been utilized in prehistoric times. These include bulbs of eastern camas (Camassia scilloidies), wild onion and garlic (Allium spp.), false garlic (Nothoscordum bivalve), rain lily (Cooperia drummondii), dog's tooth violet (Erythronium albidum), yellow-eyed grass (Hypoxis hirsute) along with tubers such as prairie turnips (Psoralea sp.), groundnut (Apios americana), and spring beauty (Claytonia virginica) (Dering 2000:219). Gould (1975) lists a number of forbs found in the Blackland Prairie. These include, but are not limited to, bluebonnet (Lupinus texensis), Mexican hat (Ratibida columnaris), sunflower (Helicanthus annuus), Indian paintbrush (Catilleja indivisa), western ragweed (Ambrosia psilostachya), and milkweed (Asclepias sp.).

As part of the Texan biotic province, Blair (1950:101) lists at least 49 species of mammals present in this province. Most species are not restricted to this one province. Common species of mammals include: Virginia opossums (Didelphis virginiana), eastern mole (Scalopus aquaticus), fox squirrel (Sciurus niger), Louisiana pocket gopher (Geomys breicepus), western harvest mice (Reitbrodontomys fulvescens), Whitefooted mice (Peromyscus leucopus), hispid cotton rat (Sigmodon hispidus), eastern cottontail (Sylvilagus floridanus), and swamp rabbit (Sylvilagus aquaticus). Two species of turtles, ornate box turtle (Terrapene ornata) and Florida box turtles (Terrapene Carolina), occur here. Sixteen species of lizards and some 39 species of snakes occur in this province. Fauna typically associated with Texas-at-large (Blair 1950; Schmidly 1994) and found within the region of interest include white-tailed deer (Odocoileus virginianus), jackrabbit (Lepus sp.), raccoon (Procyon lotor), armadillo (Dasypus novemcinctus), northern river otter (Lontra canadensis), and coyote (Canis latrans). The Ecoregions of Texas lists bison, pronghorn antelope, mountain lion, bobcat, ocelot, black bear, collared peccary, deer, coyote, fox, badger, and river otter as common species prior to European settlement (Griffith et al. 2007). 
Short Report on an Intensive Archeological Survey for the Schertz-Seguin Local Government Corporation's Proposed SH123/Austin Street Water Line Installation Project, Guadalupe County, Texas

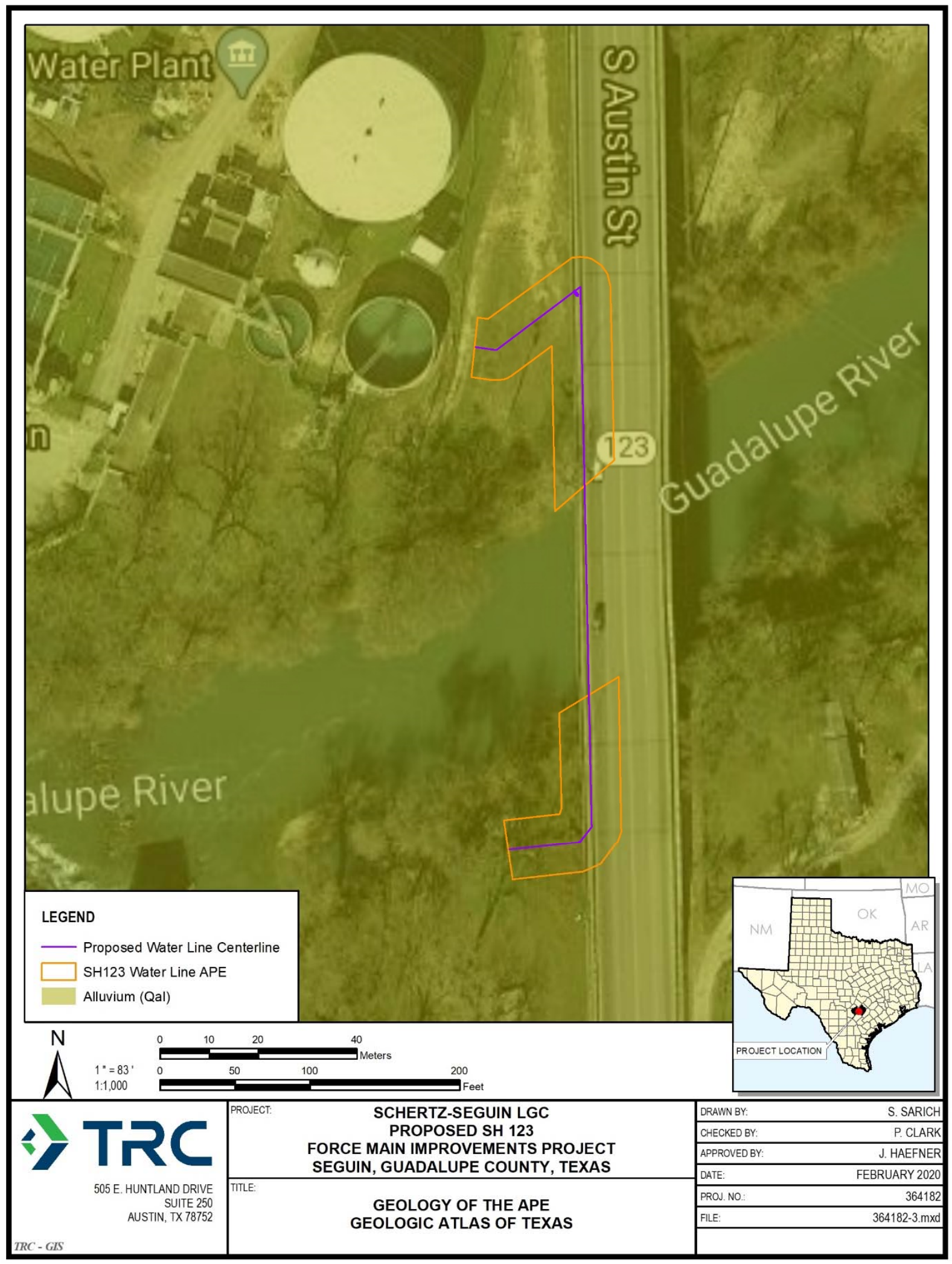

Figure 2-1 Underlying geology of the APE according to the Geologic Atlas of Texas Seguin Sheet. 


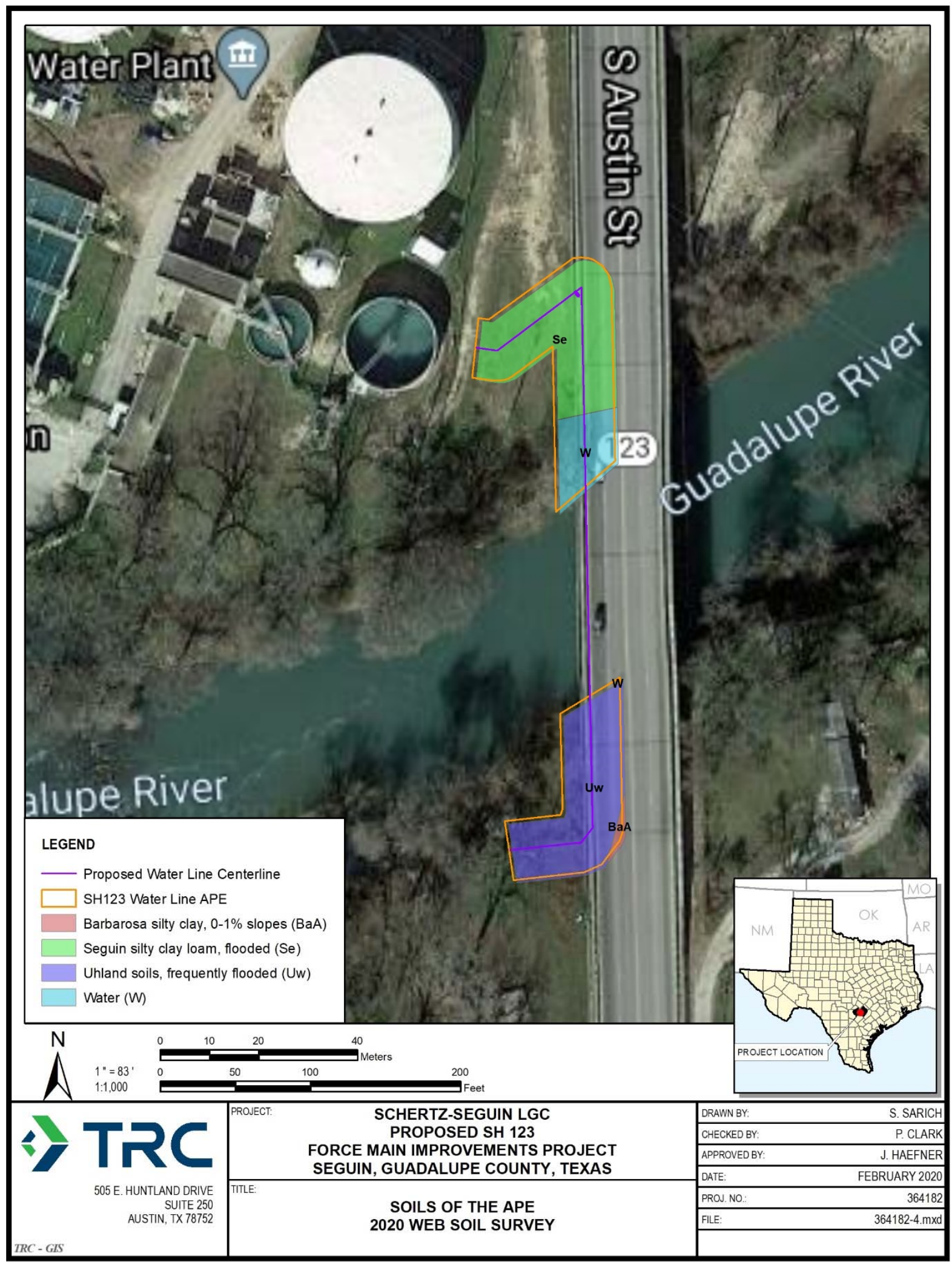

Figure 2-2 Predominant soils of the APE according to the USDA/NRCS Web Soil Survey. 
Short Report on an Intensive Archeological Survey for the Schertz-Seguin Local Government Corporation's Proposed SH123/Austin Street Water Line Installation Project, Guadalupe County, Texas

This page intentionally left blank. 


\subsection{CULTURAL HISTORY}

Archeologists in Texas have assigned cultural regions to portions of Texas that generally correspond to various physiographic characteristics of the areas. The indigenous human inhabitants of central Texas practiced a nomadic hunting and gathering lifestyle throughout all of prehistory, and, in contrast to much of the rest of North America, mobility and settlement patterns do not appear to have changed markedly through time in this region. The central Texas chronological scheme is presented below, and much of this summary is extracted from Collins $(1995,2004)$. The archeological manifestations of central Texas are divided into four broad time periods: the Paleoindian, Archaic, Late Prehistoric, and Protohistoric/Historic periods. A brief synthesis of the key characteristics of these four periods is presented below.

\subsection{PALEOINDIAN PERIOD (11,500 TO 8800 B.P.)}

Human occupations in North America are definitely established by at least 12,000 B.P. (Bement and Carter 2010; Collins 2004; Dincauze 1984; Haynes et al. 1984; Kelly and Todd 1988; Lynch 1990; Meltzer 1989; Stanford and Bradley 2012). Considerable evidence is mounting for per 12,000 B.P. human occupations (pre-Clovis populations) across North and South America (Stanford and Bradley 2012). Evidence from Meadowcroft Rockshelter in Pennsylvania indicates humans were present in Eastern North America as early as 14,000 to 16,000 years ago (Adovasio et al. 1990), and Cactus Hill in southeastern Virginia contains unmixed stratigraphic deposits from ca. 22,000 B.P. (McAvoy and McAvoy 1997), where discoveries at Monte Verde in Chile provide unequivocal evidence for human occupation in South America by at least 12,500 years ago (Dillehay 1989, 1997, 2000; Meltzer et al. 1997). Many archeologists still discount claims of much earlier human occupation during the Pleistocene glacial period (cf. Butzer 1988). In central Texas, the Levi Rockshelter contains human artifacts that potentially date to the pre-Clovis period (Alexander 1963, 1982). However, poor stratigraphy and inconsistent radiocarbon dates do not clearly reveal those artifacts in good context. More recent discoveries at the Gault site in central Texas have yielded pre-Clovis artifacts in good context below the Clovis component (Collins personal communications 2014; Stanford and Bradley 2012). Although the evidence for pre-Clovis may be sparse in general and not accepted by all researchers at present, compelling evidence exists for preClovis cultures North and South America.

The earliest well defined and most accepted period of human activities in central Texas is represented by the Paleoindian period (11,500 to 8800 B.P.) (Collins 1995). This period coincided with improved climatic conditions following the close of the Pleistocene epoch that witnessed the extinction of herds of mammoth, horse, camel, and bison. Cultures representing various sub-periods within this period are characterized by a series of distinctive, relatively large, fluted lanceolate projectile points known as Clovis that were created with a distinctive knapping technology (Collins 1999; Collins and Lohse 2004; Collins et al. 2007). Clovis hunters killed now extinct ice age animals and ranged across most of North America (see Stanford and Bradley 2012 for recent update; Texas Beyond History 2008). Following Clovis is another fluted point type referred to as Folsom and those populations were highly mobile hunters that primarily targeted large extinct bison (Bison antiquus or Bison occidentalis) (i.e., Bement 1999; Hofman 1992; Hofman et al. 1991; Jodry and Stanford 1992). Folsom sites are generally dated to between 10,900 to 10,200 B.P. (Haynes et al. 1992). These and other lanceolate projectiles including named types such as Plainview, San Patrice, Dalton, Golondrina, and other general categories including contracting stem forms like Angostura and Midland, parallel stem points like St. Mary's Hall and Scottsbluff, stemmed forms like Wilson and side-notched Big Sandy, are frequently associated with spurred end scrapers, gravers, and a suit of informal tools. 
For the latest discussion and updates of the named types and clustering of point types the reader is referred to Bousman et al. (2004). Bousman et al. (2004) also provide a complete examination of the absolute chronology for the Paleoindian period and the stratigraphic association of some of the important Texas sites. Currently, some 32 sites have been radiocarbon dated and some 243 dates are now available to facilitate the assignment of the various Paleoindian populations.

In central Texas, the Paleoindian period is divided into two sub-periods based on recognizable differences in projectile point styles. The Early Paleoindian period is recognized by fluted projectile points (i.e., Clovis and Folsom). In Texas most Clovis points, over 400 specimens, occur in surface scatters with archeological materials from later periods. Clovis points have been collected from across the state in 50 percent of the counties (Meltzer and Bever 1995). Clovis distribution is not coincident with the distribution of later Paleoindian remains. Actual Clovis sites in Texas are rare with a few exceptions such as the Gault site (Collins et al. 2011) and Pavo Real (Collins et al. 2003). The material used in manufacture of Clovis specimens is primarily Edwards Chert (Meltzer and Bever 1995). The Late Paleoindian period is characterized by unfluted lanceolate points (i.e., Wilson, Golondrina-Barber, and St. Mary's Hall). Components with these types of points date between 10,000 and 8800 B.P. However, the Plainview points along with Dalton and San Patrice-like points require further documentation to specifically place them in time in Texas.

Paleoindian groups are often inferred to have been organized into egalitarian bands consisting of a few dozen individuals that practiced a fully nomadic subsistence and settlement pattern. Due to poor preservation of floral materials, subsistence patterns in central Texas are known primarily through the study of faunal remains. Subsistence focused on the exploitation of plants, large and small animals, fish, and shellfish, even during the Paleoindian period (Collins et al. 1989). Little evidence exists in this region for hunting of extinct mega fauna (the exception being at Wilson-Leonard in Bell County for the early subperiod), as has been documented elsewhere in North America. Rather, a broad-based subsistence pattern appears to have been practiced throughout most periods. The Folsom population appears to have focused on bison hunting in other areas but also included a broad range of other taxa. Important here is the association of burned rock features with these Folsom points at Wilson-Leonard site (Collins 1989).

\subsection{ARCHAIC PERIOD (8800 TO 1200 B.P.)}

The onset of the Holocene Climate Optimum drying trend marks the beginning of the Archaic period (8000 to 1200 B.P.). This climatic trend represents a significant reorientation of lifestyle throughout most of North America, but this change was far less pronounced in central Texas. Elsewhere, the changing climatic conditions and corresponding decrease in the big game populations forced people to rely more heavily upon a diversified resource base composed of smaller game and wild plants. In central Texas, however, this hunting and gathering pattern is characteristic of most of prehistory. This period saw the intensification of hunting and gathering of local resources. With this came a more diversified tool kit, the development of an expanded ground stone assemblage, and extensive use of heated rocks (Collins 1995). The atlatl (i.e., spear thrower) and spear were the primary hunting instruments. Traditionally, the long Archaic period is subdivided into Early, Middle, and Late sub-periods based on changes in projectile points and other distinctive changes. In central Texas, the Early Archaic sub-period extends from 8800 to 6000 B.P., the Middle Archaic sub-period extends from 6000 to 4000 B.P., and the Late Archaic sub-period covers the 4000 to 1200 B.P. (Collins 1995). Changes in projectile point morphology are often used as markers 
differentiating these three sub-periods, though other changes in material culture occurred as well (Quigg et al. 2011). Perhaps most markedly, burned rock middens appear during the Middle Archaic sub-period, and continue into and through the Late Archaic sub-period. Large cemeteries also appear during the Late Archaic sub-period and mark some type of social changes. In addition, the increasing density of prehistoric sites through time is often considered to constitute evidence of population growth, though differential preservation probably at least partially accounts for the lower numbers of older sites.

\subsection{LATE PREHISTORIC PERIOD (1200 TO 400 B.P.)}

The onset of the Late Prehistoric period is defined by the appearance of the bow and arrow (Collins 1995). In central Texas, pottery also appears during the Late Prehistoric period (later than the bow and arrow and appearing earlier in east Texas by about 2500 B.P.). Agriculture came even later and only to some parts of Texas, mostly in the northeastern and northwestern parts. In Texas, unifacial arrow points appear to be associated with a small prismatic blade technology. In central Texas, two subdivisions are recognized, the Austin and Toyah phases. Austin phase sites occur earliest to the north, which has led some researchers (e.g., Prewitt 1985) to suggest that the Austin phase populations of central Texas were migrants from the north and lacked the ceramic industry of the later Toyah phase. The Austin phase continued with an Archaic subsistence pattern but the bow and arrow were definitely in use at this time. The Toyah phase replaces the Austin phase. A cluster of traits including small-stemmed arrow points, pottery, large thin bifaces, and prismatic blades characterizes the Toyah phase. These latter groups subsisted on diverse resources including bison, deer, antelope, mussels and other wild game.

One of the primary indicators of Late Prehistoric period peoples is the introduction and use of pottery. Bone (Leon Plain) and shell-tempered specimens are prevalent in occupations throughout central Texas in this period. The increased use of pottery suggest a more sedentary existence that involves less frequent travel and focus on more intensive subsistence activities, such as horticulture.

\subsection{PROTOHISTORIC PERIOD (500 TO 200 B.P.)}

The first European incursion into what is now known as Texas was in A.D. 1519, when Álvarez de Pineda explored the northern shores of the Gulf of Mexico and Port Isabel in Cameron County. In A.D. 1528, Cabeza de Vaca crossed south Texas after being shipwrecked along the Texas Coast near Galveston Bay. However, de Vaca did not approach the Colorado River basin or the Guadalupe River region and ventured across the southern part of Texas. It was not until A.D. 1691, when Domingo Terán de los Ríos, led an expedition along the route that became known as the Camino Real, located a few kilometers to the west of Seguin that exploration of this region began (McGraw et al. 1998). The European intrusion into the indigenous population created considerable conflict, rapid movements, complex interactions, and rapid change.

Excavated archeological data is also scarce for these two periods, beginning with the arrival of the first Europeans exploring the broad unknown territories. This generally reflects a period from about 500 B.P. to the present. Identified cultural resource sites in the region have not been assigned to any specific native groups and the cultural material left behind may not be characteristic enough to actually assign a cultural assemblage to a named group. Again, the lack of major excavations has limited the data necessary to address which groups were using this region at the time of European settlement. 


\subsection{HISTORIC PERIOD (200 B.P. TO 50 B.P.)}

The history of Seguin and the Guadalupe County region is too complex and varied to recount here in detail. The following summary is derived largely from Gesick (2000). For a more thorough account, the book is available online at: http://www.seguintx.net/heritage/gesicktree/gesicktreeabout.html. The Handbook of Texas Online also provides a historical summary based on Gesick's research at: http://www.tshaonline.org/handbook/online/articles/hes03.

The first European to travel through the Seguin region was Cabeza de Vaca, who crossed the Guadalupe River at the confluence with the San Marcos River sometime between 1535 and 1536. At this time, the area was occupied by semi-sedentary Lipan Apaches and Tonkawa Indians. The area around Seguin was first recorded in 1718 by Father Francisco Celiz as part of expeditions through the area conducted by the Governor of Coahuila, Martin de Alarcon. They camped just west of Seguin. By the early 19th century, Mexicans, Europeans and Anglos had settled the region, with the ranch of Jose Antonio Navarro three miles north of Seguin the closest. In 1831, the Humphries Branch was granted land along the Guadalupe River, and in 1833 built a cabin that is likely the first Anglo residence in what would later become the City of Seguin. In 1836, the Republic of Texas gained independence from Mexico. In 1838, Joseph F. Martin created a town site along a tributary of the Guadalupe River and named it Walnut Springs. The town was divided into four sections: farming lots, timber lots, acre lots, and central lots. In 1839 the name was changed to Seguin after Jaun N. Seguin. From Gesick (2000):

Juan Seguin - Organized a Company of Mexican Patriots under Sam Houston, led the cavalry charge at San Jacinto, Mayor of San Antonio, Republic Senator, fought against Americans at the 1842 Battle of Salado, self-imposed exile in Nuevo Laredo, County Judge of Wilson County during the Reconstruction period, close friend of the Austins and many military leaders of Texas, awarded a pension by the State for his military services.

In 1842, the Congress of the Republic of Texas created Guadalupe County in response to a request by the citizens of Seguin. During the Republic of Texas period (1836-1846) there were numerous altercations with the Comanche's in the Seguin area, partly as a result of agents of the Mexican government intentionally inciting rebellion among Native American groups and Mexican populations within the Republic (Gesick 2000). The Texas Rangers provided Seguin with protection during this period, and their camp was located along Walnut Branch near Guadalupe Street. Eventually, many of these Rangers would become founding residents of Seguin.

Many of the earliest homes were built from adobe. One of the earliest is the Hall-Burges-Glenwinkel home, built in 1838 by Captain Robert Hall along Walnut Branch. Other homes, like the Campbell Log Cabin, currently located on East Live Oak Street, were built from timber. There were at least a dozen homes in Seguin by 1840 . By 1845 the first school classes were being taught in an adobe building at the corner of Milam and Nolte Streets. By 1850 a high school was built from concrete on South Austin Street by Dr. John Parks and is now the Saint James Catholic School.

In 1845 the United States annexed Texas. The majority of voters approved of the annexation and the new state's constitution that sanctioned slavery and the immigration of slave owners to Texas. The 1840's and 1850's saw a wave of immigration to Texas by Germans and other Europeans, many who passed through Seguin on their way westward. This created a boom for the local economy and the period from 1845 to 
1860 fueled construction of buildings and infrastructure, including a stage coach route. By 1860 at least 100 concrete structures had been built, of which 29 are still standing (Gesick 2000).

The residents of Seguin were pro-slavery by 1860 and two military camps had been created in Guadalupe County. In 1961 Company D, led by Captain Nathanial Benton was organized and assembled at the Seguin courthouse on June 28th. The Company would eventually travel as far east as Virginia and participate in the battles of Etham's Landing, Seven Pines, and Gaines Mill. When General Lee surrendered in 1865, 18 of the original members of Company D were present. Three residents of Seguin would become Generals in the Confederacy. The Civil War period saw a decline in the prosperity Seguin had experienced in the 1840's and 1850's. However, given that no fighting occurred within Seguin, there was no destruction of farms or communities as experienced in other parts of the Confederacy.

In 1867 the Freedmans Bureau was created across from Market Square and Union soldiers were stationed along Live Oak Street to enforce Reconstruction laws and assist freed slaves. Public education for African American children was offered in 1871, and largely aided by Baptist and Methodist churches. By 1874, the City had partly recovered from the economic downturn created during the Civil War, and some African American families were landowners. The economic recovery was partially fueled by a shift towards cattle ranching.

In 1876, African American citizens of Seguin created the Abraham Lincoln School, which later became the Ball High School in 1925. The school was name after Reverend William Baton Ball, who was instrumental in providing education to the African American community. From 1887-1936, Guadalupe College, provided college level education for African Americans. In 1912 Texas Lutheran College was from Brenham to Seguin and was renamed Texas Lutheran University in 1996.

The discovery of oil in the Darst Creek fields in the 1920's provided Seguin with a welcomed economic boost, and the City continued to produce notable residents. From the Handbook of Texas Online:

State Senator Ferdinand C. Weinert of Seguin was responsible for long-lasting prison reforms and also worked to establish the Pasteur Institute of Texas, which saved many lives in the treatment of rabies. Hilda Blumberg Weinert's contributions to education and politics in Texas were also important. As the twentieth century progressed Seguin attracted manufacturing and serviceoriented industries to diversify its agricultural and oil-based economy. In 1986 the Seguin city government changed from the mayor-council form of city government to the council-manager form of city government. By 1988 the town had an estimated population of 22,000 and more than thirty businesses that employed more than fifteen full-time workers each. By that year also the county hospital had expanded to seventy-five beds. The Seguin-Guadalupe County Library continued its expansion to more than 50,000 volumes, and the Seguin Gazette-Enterprise celebrated its centenary year in 1988. On August 12, 1988, Seguin celebrated its sesquicentennial year. Tourists were attracted to Max Starcke Park, the Guadalupe County Coliseum, and the County Fairgrounds, where the Texas State High School Rodeo has been held since 1984. The town boasted a number of antebellum homes, including the Sebastopol House State Historic Structure, and the greater Seguin area was the setting for author Janice Woods Windle's successful novel True Women (1993), featured in a television miniseries in 1997. In 2000 Seguin had a population of 22,011 and 1,338 businesses. 
Short Report on an Intensive Archeological Survey for the Schertz-Seguin Local Government Corporation's Proposed SH123/Austin Street Water Line Installation Project, Guadalupe County, Texas

This page intentionally left blank. 


\subsection{PREVIOUS INVESTIGATIONS AND PREVIOUSLY RECORDED CULTURAL RESOURCES}

TRC archeologists conducted a limited desktop literature and archives review for the proposed Project to assess whether previously recorded cultural resources are within or adjacent to the APE or within a 1-mi (1.6- km) of the APE. This included a review of the Texas Historical Commission's (THC) Archeological and Historic Sites Atlas (Atlas) which provides information related to the location of previously conducted archeological surveys and recorded archeological sites, cemeteries, properties currently listed or eligible for listing on the NRHP, Recorded Texas Historic Landmarks, and SALs that may be impacted by the proposed Project. According to the THC-Atlas, no previously conducted archeological surveys intersect or are adjacent to the APE. Three previous surveys were conducted within 1-mi of the APE. No archeological sites are within or are adjacent to the APE (Figure 4-1).

Previous survey information is presented in Table 1. No archeological sites are within or are adjacent to the APE, however three sites are within 1-mi of the APE. None of these three sites are currently listed on the NRHP or are designated SALs; however, site 41GU117 is recommended for further work by the site recorder. No cemeteries or historic properties are within or adjacent to the APE; however, two cemeteries and NRHP properties were identified within 1-mi of the APE. Information on these cultural resources is also presented in Table 2. Thirteen historical markers are present within 1-mi of the APE and are presented in Table 3. 
Short Report on an Intensive Archeological Survey for the Schertz-Seguin Local Government Corporation's Proposed SH123/Austin Street Water Line Installation Project, Guadalupe County, Texas

Figure Redacted Due To Site Sensitive Data.

Figure 4-1 Previously recorded cultural resources and surveys within 1-mile of the APE. 
Table 1. Previous archeological surveys within 1-mile of the APE (THC 2020).

\begin{tabular}{|c|c|l|c|}
\hline $\begin{array}{c}\text { Distance and Direction } \\
\text { from APE (miles=mi) }\end{array}$ & $\begin{array}{c}\text { Date of } \\
\text { Survey }\end{array}$ & \multicolumn{1}{|c|}{ Description } & Atlas Number \\
\hline $\begin{array}{c}\text { Archeological Survey, 0.27 } \\
\text { mi northeast }\end{array}$ & 1997 & $\begin{array}{l}\text { Unknown cultural survey was conducted in 1997 } \\
\text { for Texas Parks and Wildlife Department. No } \\
\text { additional information was available in the THC- } \\
\text { Atlas }\end{array}$ & 8500000098 \\
\hline $\begin{array}{c}\text { Archeological Survey, 0.39 } \\
\text { mi northeast }\end{array}$ & 2013 & $\begin{array}{l}\text { Jacobs conducted a survey in 2013 for USACE - } \\
\text { Fort Worth District and the City of Seguin for the } \\
\text { Walnut Branch Restoration Project. No } \\
\text { Archeological sites were encountered. No further } \\
\text { information was available in the THC-Atlas. TAC } \\
\text { Permit \#6110. }\end{array}$ & 8500029747 \\
\hline $\begin{array}{c}\text { Archeological Survey, 0.9 mi } \\
\text { north }\end{array}$ & 2013 & $\begin{array}{l}\text { Survey was conducted for the Walnut Branch } \\
\text { Hike and Bike Survey in 2013 by HRA Gray and } \\
\text { Pape for Texas Department of Transportation. No } \\
\text { archeological sites were recorded. No additional } \\
\text { information was available in the THC-Atlas. TAC } \\
\text { Permit \#6464. }\end{array}$ & 8500048594 \\
\hline
\end{tabular}

Table 2. Cultural resources identified within 1-mile of the APE (THC 2020).

\begin{tabular}{|c|c|c|c|}
\hline $\begin{array}{c}\text { Resource } \\
\text { Type }\end{array}$ & Name & Comments & $\begin{array}{c}\text { NRHP } \\
\text { Eligibility }\end{array}$ \\
\hline $\begin{array}{l}\text { Historic and } \\
\text { Prehistoric } \\
\text { Archeological } \\
\text { Site, } 0.88 \mathrm{mi} \\
\quad \text { north }\end{array}$ & 41GU114 & $\begin{array}{l}\text { (West bank of Walnut Branch Creek) } \\
\text { The site was recorded by Center for Archaeological Research-The } \\
\text { University of Texas at San Antonio during the Walnut Branch Hike and } \\
\text { Bike Pedestrian Survey (2008). Cultural material consisted of historic } \\
\text { and a minimal amount of prehistoric material. Artifacts consisted of } \\
\text { burned rock }(n=5) \text {, historic ceramics }(n=3) \text {, debitage }(n=1) \text {, glass }(n=9) \text {, } \\
\text { metal }(n=2) \text {, and slate. No further work was recommended for the site. }\end{array}$ & $\begin{array}{l}\text { Ineligible within } \\
\text { right of way. }\end{array}$ \\
\hline $\begin{array}{l}\text { Historic and } \\
\text { Prehistoric } \\
\text { Archeological } \\
\text { Site, } 270 \mathrm{ft} \\
\quad \text { east }\end{array}$ & 41GU117 & $\begin{array}{l}\text { The site was recorded in April } 2008 \text { by the Texas Archeological } \\
\text { Stewardship Network and ranges in dates from the Late Paleolithic } \\
\text { period to the Late Archaic as well as an unidentified historic component. } \\
\text { Various projectile points and scrapers represent the prehistoric } \\
\text { component of the site, while trade items such as turquoise nuggets and } \\
\text { seashells are indicative of a historic component. Neither natural nor } \\
\text { artificial impacts have been noted and further testing is recommended. }\end{array}$ & Unassessed \\
\hline $\begin{array}{l}\text { Historic } \\
\text { Archeological } \\
\text { Site, } 0.92 \mathrm{mi} \\
\text { north }\end{array}$ & 41GU166 & $\begin{array}{l}\text { The site (Hugman's replicated rock wall) was recorded by TRC in } 2013 \\
\text { during the Walnut Branch Sewer Replacement Project and consists of a } \\
\text { linear rock wall constructed of native field stones and local concrete and } \\
\text { mortar. The wall may have been constructed under WPA project } \\
\text { funding as a local park and significant as part of Seguin's early park } \\
\text { development. }\end{array}$ & Unassessed \\
\hline $\begin{array}{c}\text { Cemetery, } \\
0.69 \mathrm{mi} \\
\text { northeast }\end{array}$ & $\begin{array}{l}\text { Riverside } \\
\text { (Riverview) } \\
\text { Cemetery }\end{array}$ & $\begin{array}{l}\text { Large cemetery in Seguin located on East Klein Street at South River } \\
\text { Street. }\end{array}$ & Not Eligible \\
\hline $\begin{array}{l}\text { Cemetery, } \\
0.65 \text { mi north }\end{array}$ & $\begin{array}{l}\text { Juan Seguin } \\
\text { Burial Site }\end{array}$ & $\begin{array}{l}\text { Burial site located off Fair and S. Guadalupe Streets for Juan Seguin } \\
\text { and the grave is covered with a marble slab. The site is part of the city } \\
\text { park system. }\end{array}$ & Not Eligible \\
\hline $\begin{array}{l}\text { NRHP } \\
\text { Property, } 302 \\
\text { ft west }\end{array}$ & $\begin{array}{l}\text { Saffold Dam } \\
\text { (Starcke Park } \\
\quad \text { Dam) }\end{array}$ & $\begin{array}{l}\text { The dam is situated across the Guadalupe River approximately } 450 \mathrm{ft} \\
\text { upstream from } \mathrm{SH} 123 \text { bridge. The dam was originally a line of boulders } \\
\text { across the riverbed, but now is a series of three reverse curves } \\
\text { approximately } 250 \mathrm{ft} \text { in length and } 3-40 \mathrm{ft} \text { wide. A small concrete wall, } \\
\text { approximately } 1.5 \mathrm{ft} \text { high forms the crest of the dam. The overall height } \\
\text { of the dam varies as high as } 16 \mathrm{ft} \text {. The dam construction (c. 1853) is } \\
\text { linked to the settling of Seguin. }\end{array}$ & Eligible \\
\hline $\begin{array}{l}\text { NRHP } \\
\text { Property, } \\
0.84 \text { mil } \\
\text { northwest }\end{array}$ & $\begin{array}{l}\text { Joseph F. } \\
\text { Johnson } \\
\text { House }\end{array}$ & $\begin{array}{l}\text { (761 Johnson Avenue) } \\
\text { The Joseph F. Johnson House at } 761 \text { Johnson Avenue is situated on } \\
1.09 \text { ac of land with a large bell- shaped cistern, two hand dug wells, } \\
\text { and all the subsidiary buildings have been destroyed. They included a } \\
\text { small slip-form concrete building that served as the slave quarters and } \\
\text { a log and adobe structure. They were razed in the early } 1960 \text { 's. The } \\
\text { Johnson House is a two-story dwelling with cellar that was constructed } \\
\text { in concrete from a method that closely resembles current slip-form } \\
\text { methods. There are two chimneys that serve one fireplace and two } \\
\text { flues for wood burning stoves. Roof pitch is approximately six to twelve } \\
\text { and was roofed originally with hand split cypress shakes, which are now } \\
\text { covered with a metal seam roof. }\end{array}$ & Eligible \\
\hline
\end{tabular}


Short Report on an Intensive Archeological Survey for the Schertz-Seguin Local Government Corporation's Proposed SH123/Austin Street Water Line Installation Project, Guadalupe County, Texas

Table 3. Historical markers located within 1-mile of the APE (THC 2020).

\begin{tabular}{|c|c|l|l|}
\hline $\begin{array}{c}\text { Resource Type within a 1-mile radius } \\
\text { of APE }\end{array}$ & $\begin{array}{c}\text { Marker } \\
\text { Number }\end{array}$ & \multicolumn{1}{|c|}{ Marker Name } & \multicolumn{1}{|c|}{$\begin{array}{c}\text { NRHP } \\
\text { Eligibility }\end{array}$} \\
\hline Historical Marker & 18787 & Second Baptist Church of Seguin & N/A \\
\hline Historical Marker & 3458 & Moore House & N/A \\
\hline Historical Marker & 2300 & Guadalupe River & N/A \\
\hline Historical Marker & 4436 & Saffold Dam & Eligible \\
\hline Historical Marker & 2452 & Henry Troell & N/A \\
\hline Historical Marker & 5494 & Timothy Pickering & N/A \\
\hline Historical Marker & 1521 & Ezekiel Smith & N/A \\
\hline Historical Marker & 898 & Claiborne West & N/A \\
\hline Historical Marker & 2841 & Jonathan Douglas & N/A \\
\hline Historical Marker & 2778 & John F. McGuffin & N/A \\
\hline Historical Marker & 4515 & Samuel Millett & N/A \\
\hline Historical Marker & 4279 & Riverside Cemetery & N/A \\
\hline Historical Marker & & \\
\hline
\end{tabular}


This page intentionally left blank 


\subsection{RESEARCH OBJECTIVES AND METHODS}

The archeological investigations described in this report were undertaken with the following goals in mind:

- Determine if cultural resources are present within the APE;

- If cultural resources are present within the APE, attempt to determine their spatial extent within the APE;

- If cultural resources are present within the APE, attempt to determine the general age and context of these deposits.

Fieldwork was conducted by TRC archeologists Steven Sarich and Benjamin Johnson on February 12, 2020 and followed the guidelines and survey standards set forth by the CTA. After review of the project plans, it was determined that of the approximately $155 \mathrm{~m}$ proposed water line only $27 \mathrm{~m}$ of the line to the north and $18 \mathrm{~m}$ of the line to the south would be buried with the remainder above ground and spanning the Austin Street bridge (Figure 5-1). Survey efforts were concentrated along the buried portions of the proposed water line. Detailed design plans can be found in Appendix A.

The field effort consisted of pedestrian survey supplemented with shovel testing of the APE. Minimally, TRC excavated shovel tests or recorded 'No Dig' observation points at $15 \mathrm{~m}$ transect spacing with intervals no greater than $30 \mathrm{~m}$. Shovel tests were approximately 30- to 40-centimeteres (cm) (11.8 inches [in]) in diameter, and excavated to at least 80 centimeters in depth, the base of Holocene deposits, or impenetrable bedrock, whichever was encountered first. Excavated soils were screened through $1 / 4$-inch (6.25 millimeter) hardware mesh to ensure consistent artifact recovery. Standardized field notes were maintained for each shovel test describing location, soil depth, color, texture, stratigraphy, as well as the types of artifacts recovered. The location and results of all shovel tests were recorded on electronic forms created by TRC with Fulcrum, a mobile form builder and data collection program. In certain circumstances, shovel tests were not excavated due to the presence of existing utilities, presence of existing bridge construction, or presence of steep slope. These locations were documented and designated as 'No Dig' points. Representative project overview photographs and shovel test photographs were taken throughout the project. 


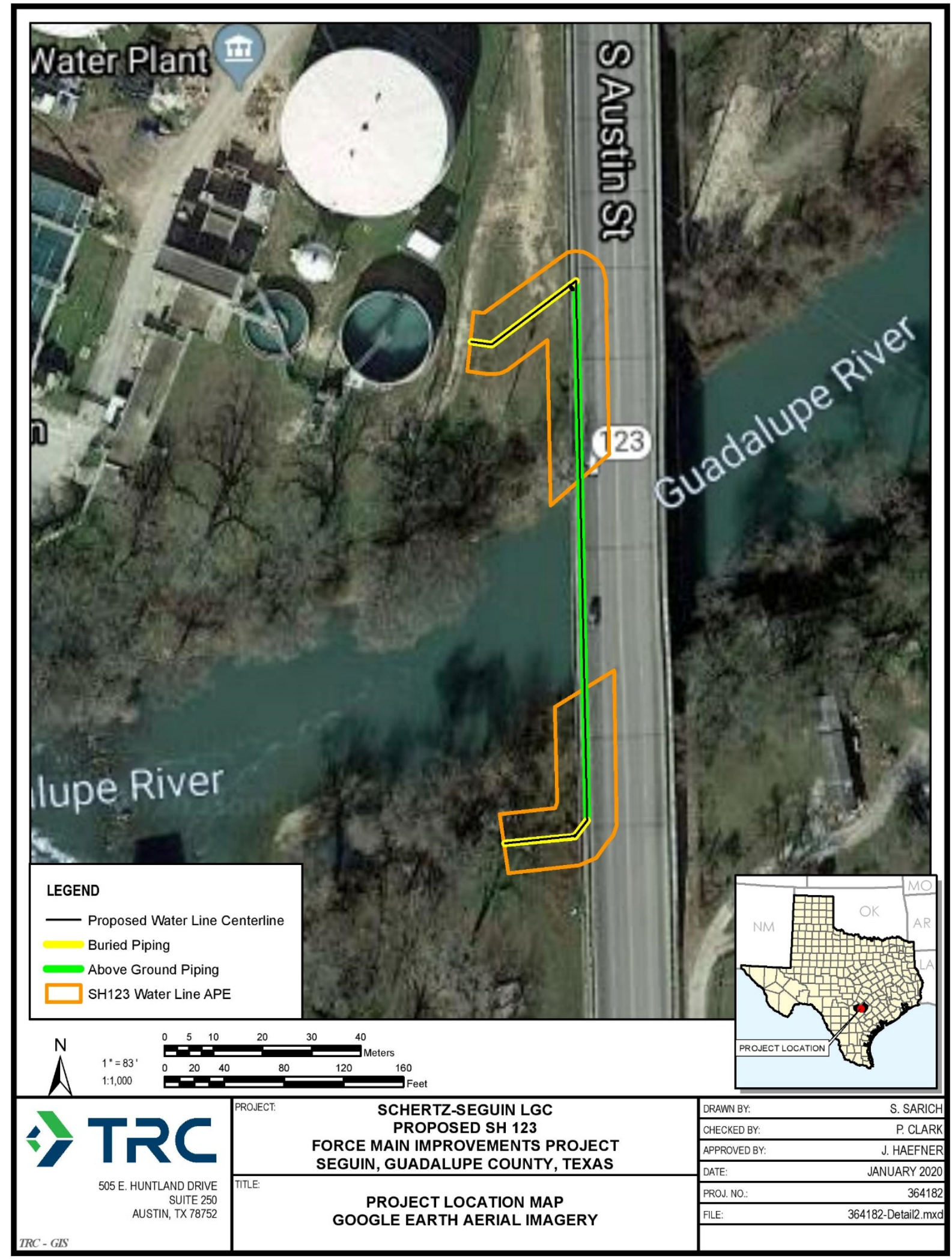

Figure 5-1 Detailed view of the APE with buried (yellow) and above ground (green) water line piping. 
Short Report on an Intensive Archeological Survey for the Schertz-Seguin Local Government Corporation's Proposed SH123/Austin Street Water Line Installation Project, Guadalupe County, Texas

This page intentionally left blank. 


\subsection{INTENSIVE SURVEY RESULTS}

\subsection{SUMMARY OF INTENSIVE SURVEY DATA}

During the cultural investigations conducted on February 12, 2019, a total of one shovel test was excavated and nine 'No Dig' observation points were recorded across 0.35 total ac. Survey results for each location are presented in Figure 6-1 and Figure 6-2. Shovel test data is presented in Appendix B. The single excavated shovel test (1-SS) within the northern portion of the APE was located $5 \mathrm{~m}$ east of and adjacent to the perimeter fencing surrounding the water plant facility on a raised berm (Figure 6-3). The shovel test exhibited 40 to 50 percent medium to coarse, sub-rounded gravel within dark brown (7.5YR 4/4), sandy loam soil. The soil exhibited additional dark brown (7.5YR 2.5/2) and light brown (7.5YR 6/6) mottling. The gravel content increased toward the base of the shovel test and limited the depth to approximately 20 cmbs (Figure 6-4). The soils within the shovel test indicated the area had undergone substantial modification related either to the construction of the water facility or the construction of the bridge. Three 'No Dig' shovel tests (1-BJ, 2-BJ, and 2-SS) were recorded within close proximity to or overlapping an existing buried gas pipeline or existing water line and therefore were not excavated (Figures 6-5). 'No Dig' point 3-SS coincided with an existing bridge pier, water line, and the edge of a slope down to the Guadalupe River (Figure 6-6).

After visual inspection of the southern portion of the APE, no shovel tests were excavated in this area and five 'No Dig' observation points were recorded (3-BJ, 4-BJ, 4-SS, 5-SS, and 6-SS). The entirety of the southern portion of the APE is situated on a steep slope and coincides with the sloped bridge abutment (Figure 6-7). The observation points are in close proximity or overlapping the existing buried gas pipeline that continues across the river and the existing water line (Figure 6-8). 'No Dig' observation point 4-SS is approximately 1 to $2 \mathrm{~m}$ south of a transmission line pole (see Figure 6-7). Additionally, the APE is located within the current flood plain of the Guadalupe River with soils designated as flooded or frequently flooded. According to the National Flood Hazard Layer the APE is located with a Regulatory Floodway zone and/or Zone A 100-year floodplain (FEMA 2020). Soil components meet the hydric criteria for soils that are frequently ponded for long or very long durations during the growing season (Criteria 3 ) or are frequently flooded for long durations or very long durations during the growing season (Criteria 4) (USDA Web Soil Survey 2020). The survey did not identify any subsurface cultural resources in the excavated shovel test. No surface artifacts, cultural features, or historic standing structures were observed within the APE during the February 2020 survey. 
Short Report on an Intensive Archeological Survey for the Schertz-Seguin Local Government Corporation's Proposed SH123/Austin Street Water Line Installation Project, Guadalupe County, Texas

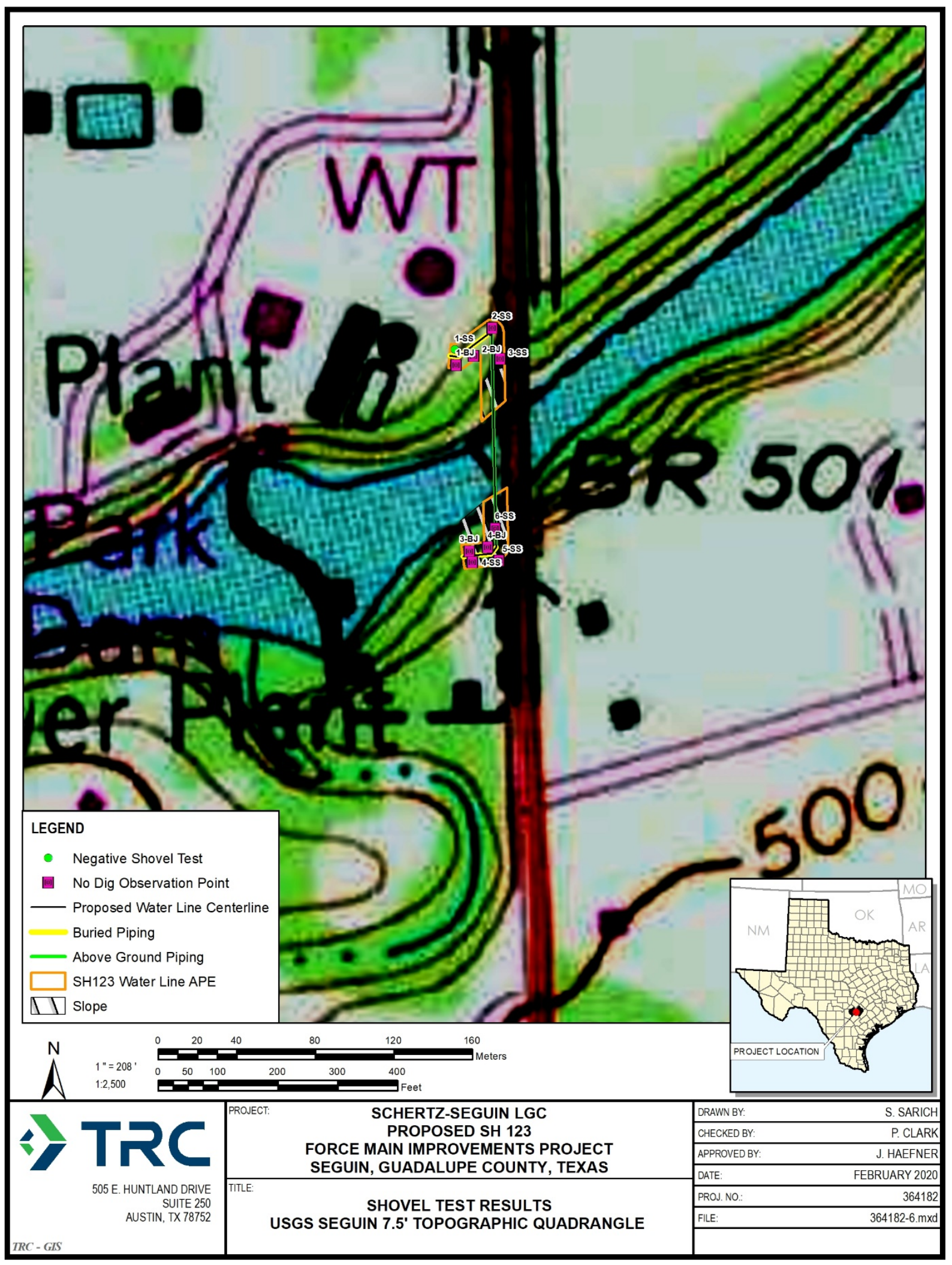

Figure 6-1 Shovel test results map on USGS Seguin 7.5' topographic quadrangle. 


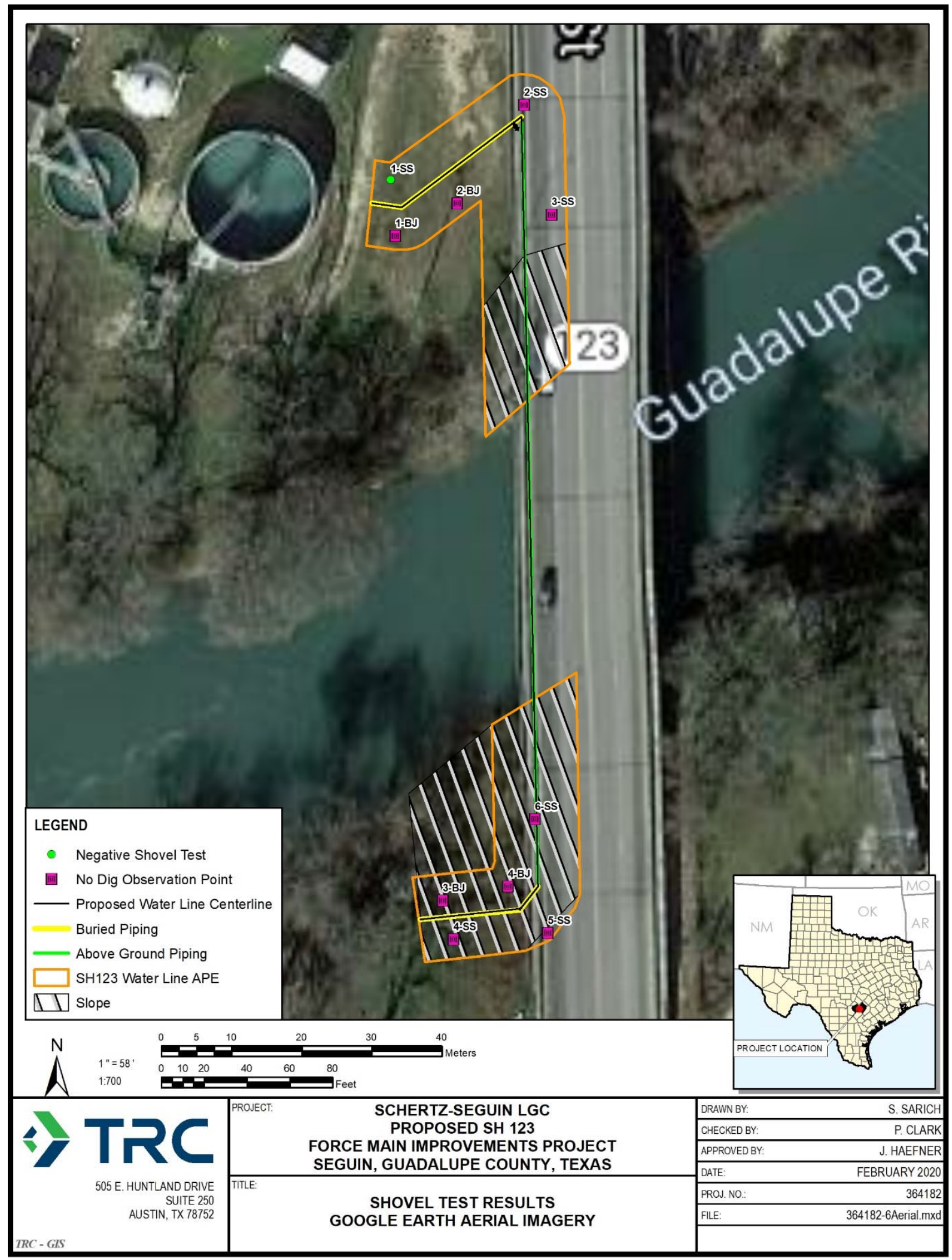

Figure 6-2 Shovel test results map on aerial imagery. 

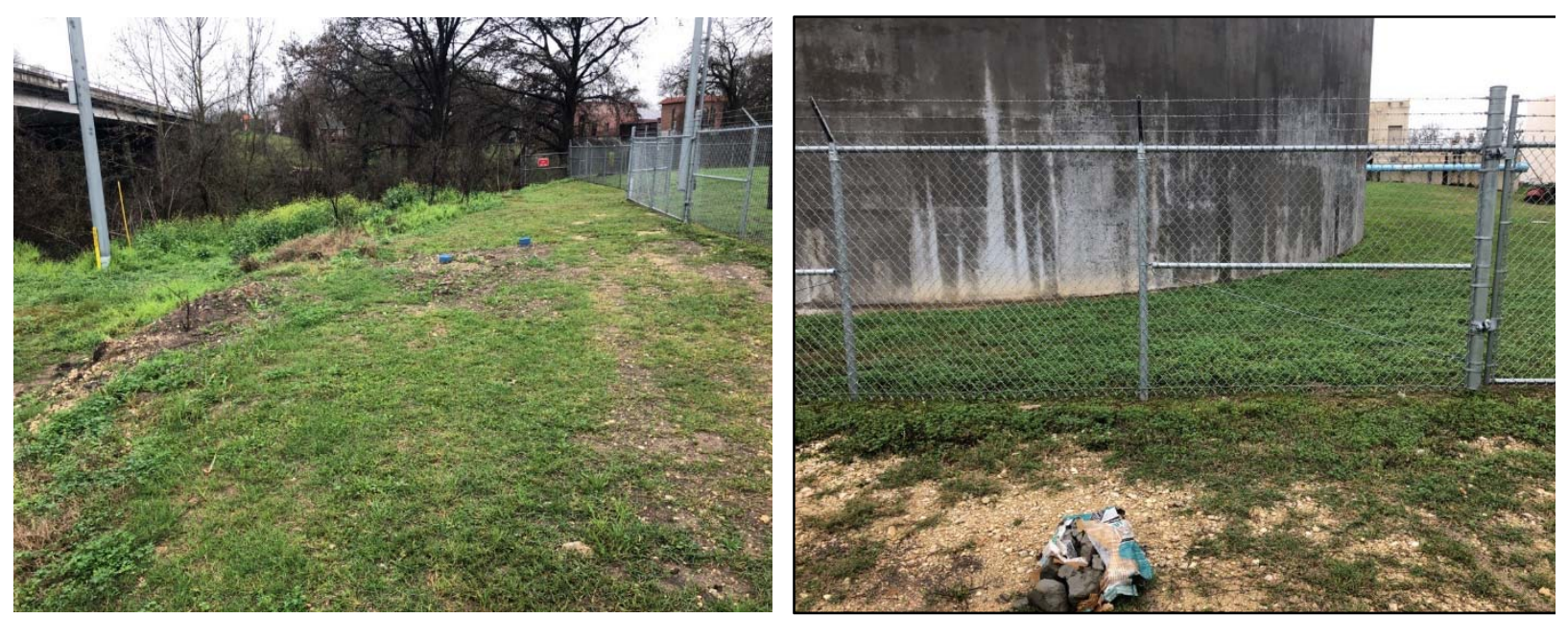

Figure 6-3 Overviews at area conditions and water facility surrounding shovel test 1-SS, facing south and west (left to right).

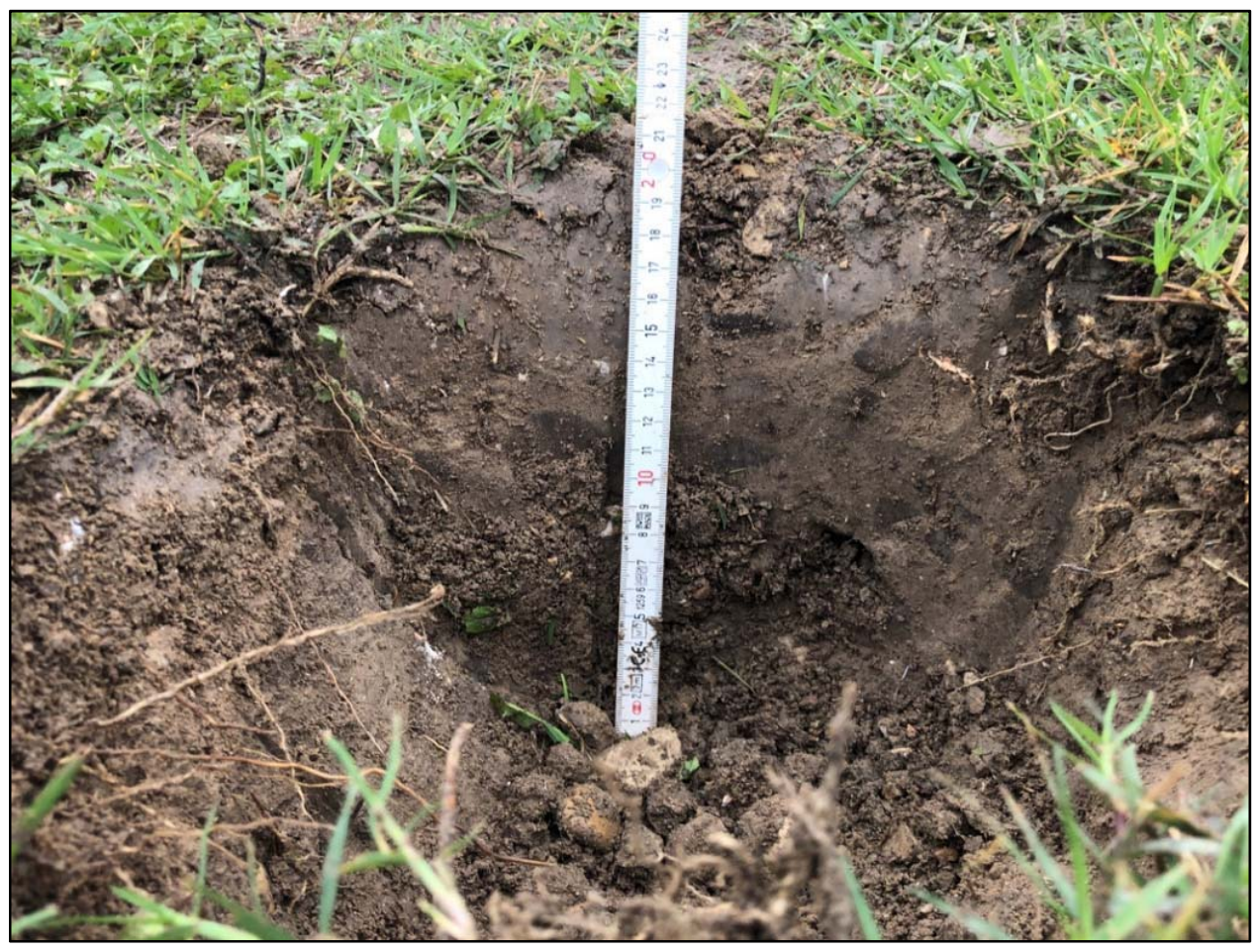

Figure 6-4 Shovel test profile for 1-SS showing gravel and mottled soil conditions, facing south. 

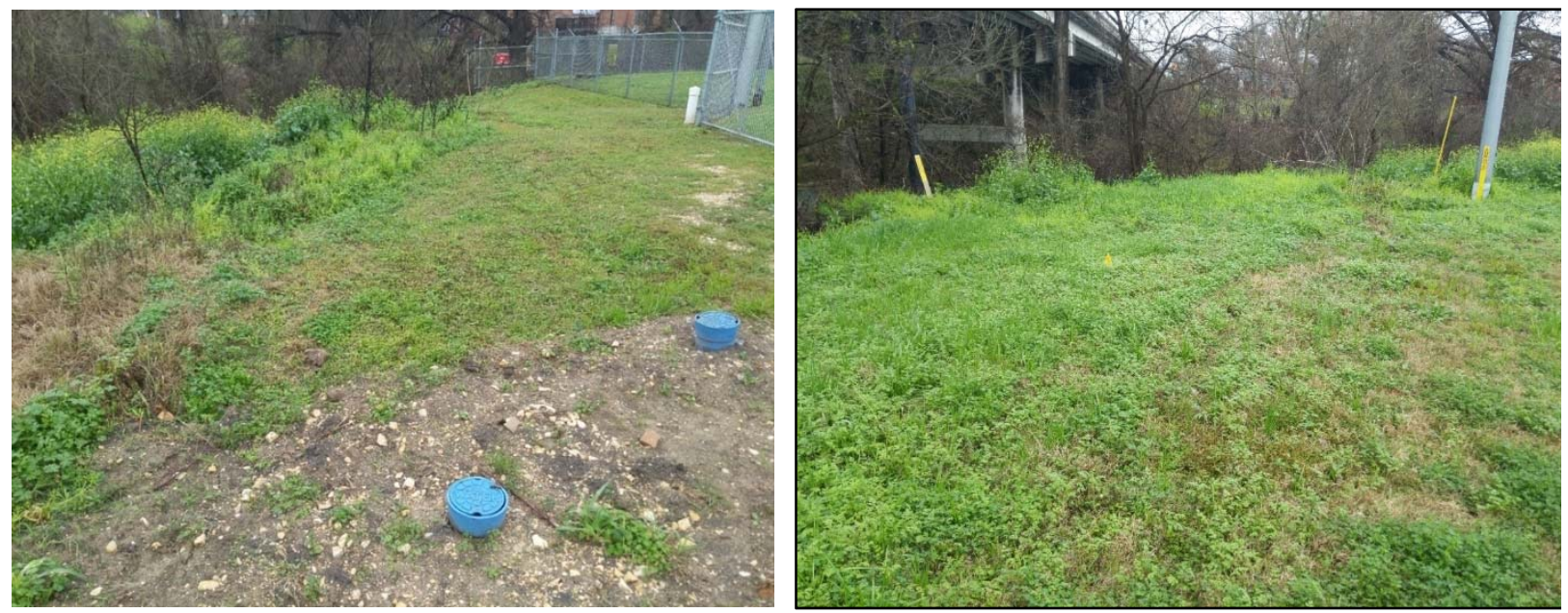

Figure 6-5 Overviews of the existing water line and existing gas line in the northern portion of the APE, facing south.
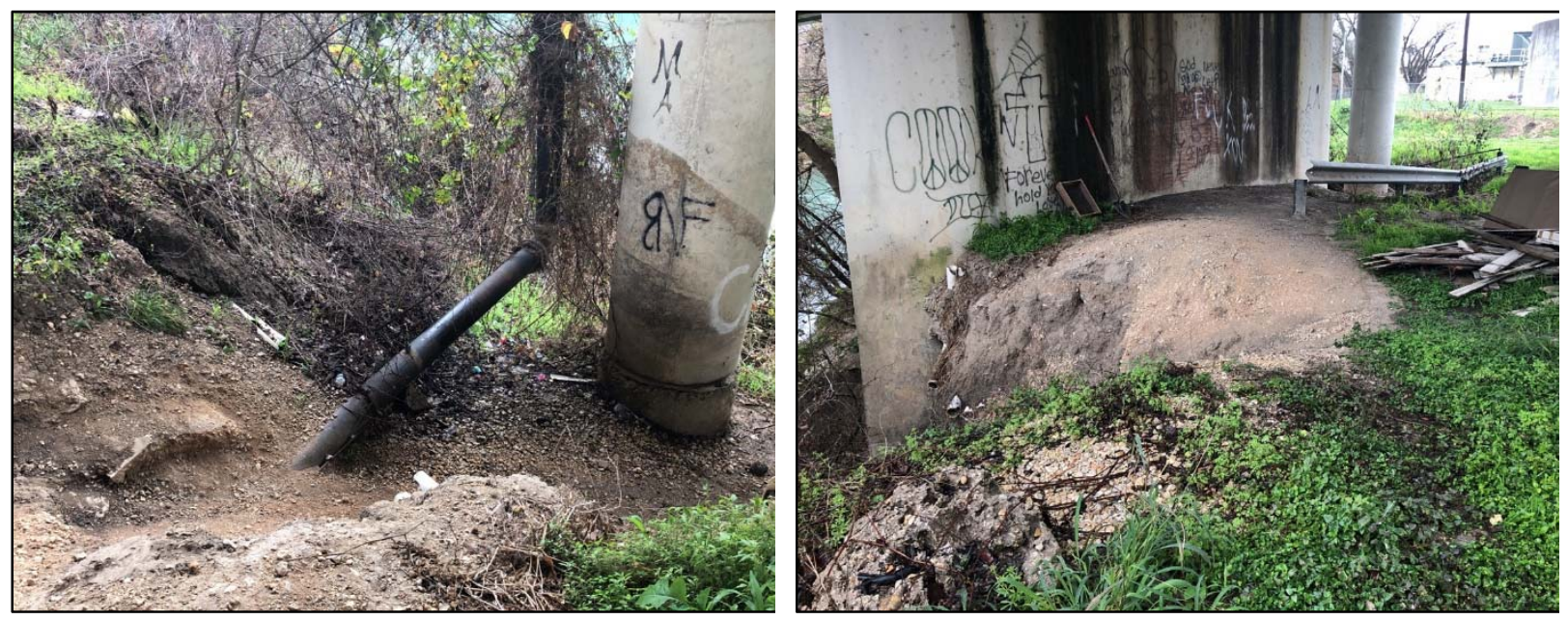

Figure 6-6

Overviews of the ground disturbance from bridge construction and steep slope to river, facing east and west (left to right). 
Short Report on an Intensive Archeological Survey for the Schertz-Seguin Local Government Corporation's Proposed SH123/Austin Street Water Line Installation Project, Guadalupe County, Texas
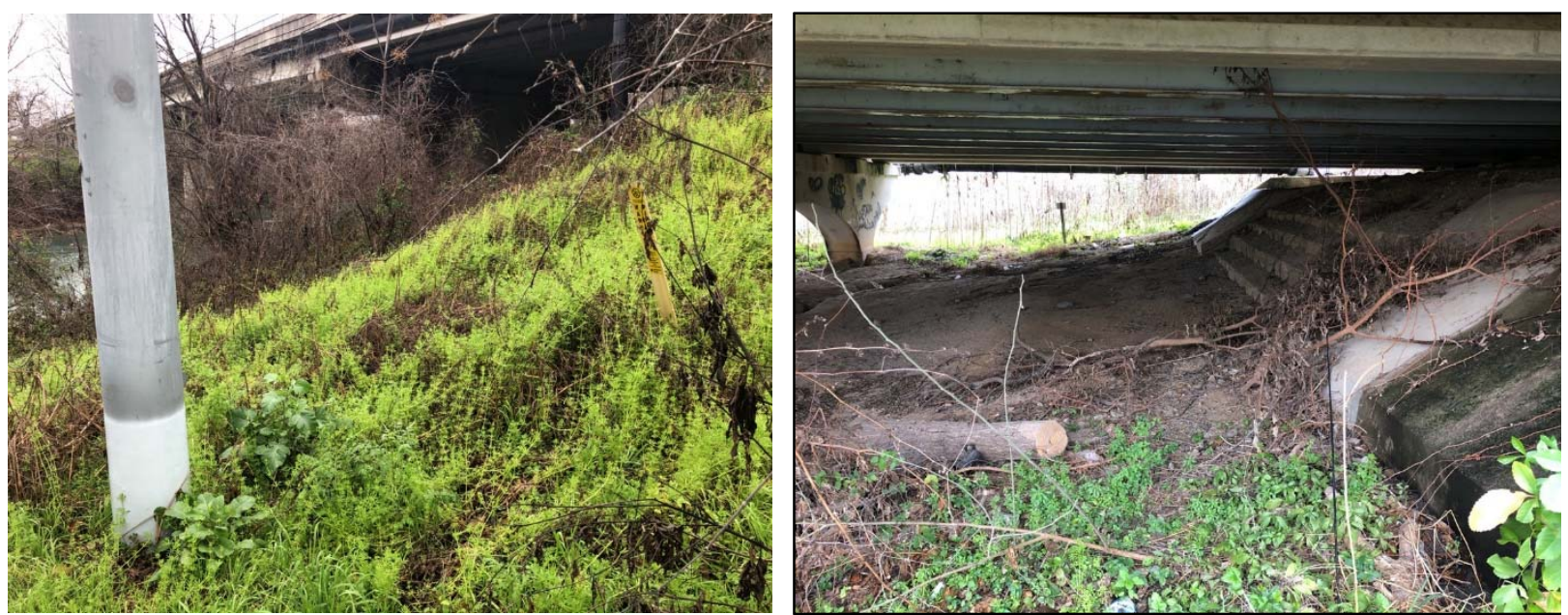

Figure 6-7 Overviews of the southern portion of the APE showing steep slope adjacent to bridge abutment, facing north and east (left to right).

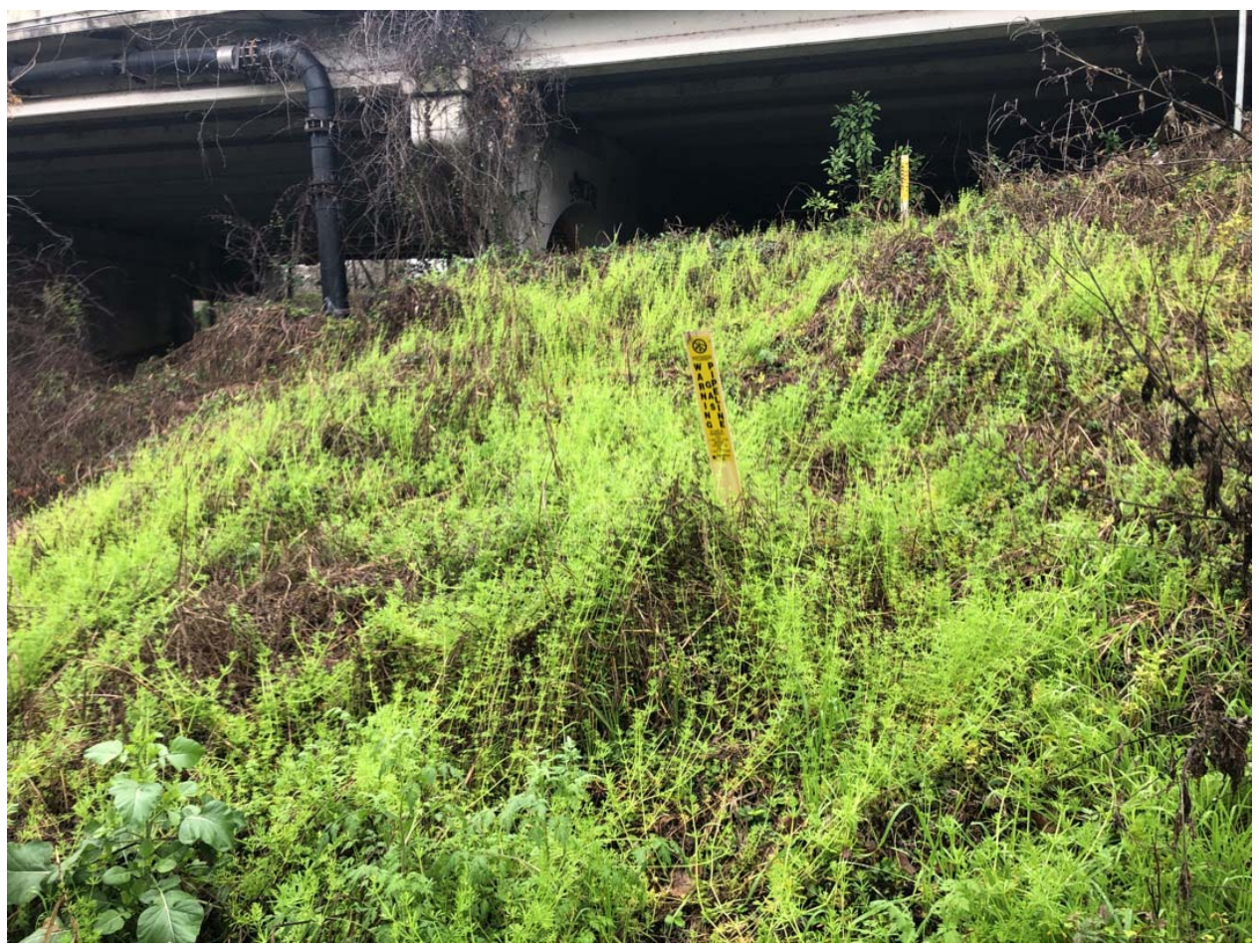

Figure 6-8

Overview of the southern portion of the APE showing the existing gas line and water line, facing east. 


\subsection{SUMMARY AND RECOMMENDATIONS}

Schertz-Seguin Local Government Corporation is proposing to construct an 18-inch water main pipeline along the west side of State Highway (SH) Business 123 (Stockdale Highway/South Austin Street) crossing of the Guadalupe River in the City of Seguin, Guadalupe County, Texas (Project). The proposed pipeline will connect existing pipeline on the north side of the crossing and an existing main pipeline on the south side of the crossing. The Project is within the City of Seguin, an entity of the state of Texas, and thus triggers a review of cultural resources under the Antiquities Code of Texas (Section 191.0525). Additionally, due to USACE permitting requirements the Project falls under the regulations of Section 106 of the National Historic Preservation Act of 1966, as amended (U.S. Code 16, §470, et seq.).

To meet its responsibilities under state and federal statutes, the Client contracted TRC to conduct the necessary cultural resources survey. TRC submitted a Texas Antiquities Permit Application to the THC and subsequent fieldwork was performed under Antiquities Permit number 9263.

Fieldwork was conducted by TRC archeologists Steven Sarich and Benjamin Johnson on February 12, 2020. The field effort consisted of pedestrian survey supplemented with shovel testing of the 0.35 ac APE concentrated around the buried lengths of the proposed water line. Due to the high degree of ground disturbance from existing utilities, bridge construction, and the presence of steep slope, a majority of the shovel test points were recorded as 'No Dig' observation points. Only a single shovel test could be excavated and exhibited evidence of modified soils from either water facility construction, bridge construction, or a combination of both.

Because of the high degree of existing ground disturbance, steep slope, and the frequency of flooding due to the location of the APE within the floodplain immediately adjacent to the banks of the Guadalupe River the likelihood for deeply buried archeological sites is low. If deeply buried archeological sites are present, there is a low potential for site integrity. No subsurface, surficial cultural resources, or historic structures were identified within the APE. No additional work is recommended. 
Short Report on an Intensive Archeological Survey for the Schertz-Seguin Local Government Corporation's Proposed SH123/Austin Street Water Line Installation Project, Guadalupe County, Texas

This page intentionally left blank. 


\subsection{REFERENCES CITED}

Adovasio, J. M., J. Donahue, and R. Stuckenrath

1990 The Meadowcroft Rockshelter Chronology 1975-1990. American Antiquity 55:348- 354.

Alexander, H. J.

1963 The Levi site: a Paleo-Indian Campsite in Central Texas. American Antiquity 28:510- 528.

1982 The Pre-Clovis and Clovis Occupations at the Levi Site. In Peopling of the New World, edited by J. E. Ericson, R. E. Taylor and R. Berger, pp. 133-145. Los Altos, California, Ballena Press.

Bement, L. C.

1999 Bison Hunting at Cooper Site: Where Lighting Bolts Drew thundering Herds. University of Oklahoma Press, Norman.

Bement, L. C. and B. J. Carter

2010 Jake Bluff: Clovis Bison Hunting on the Southern Plains of North America. American Antiquity 75(4):907-933.

Blair, W.F.

1950 The Biotic Provinces of Texas. Texas Journal of Science 2(1):31-117

Bousman, C. B., B. W. Baker, and A. C. Kerr

2004 Paleoindian Archeology in Texas. In The Texas Prehistory, edited by T. K. Perttula, pp. 15-97. Texas A\&M University Press, College Station.

Butzer, K. W.

1988 A Marginality Model to Explain Major Spatial and Temporal Gaps in the Old and New World Pleistocene Settlement Records. Geoarcheology 3:193-203.

Collins, M. B.

1995 Forty Years of Archeology in Central Texas. Bulletin of the Texas Archeological Society 66:361-400.

1999 Clovis Blade Technology. The University of Texas Press, Austin.

2004 Archeology of Central Texas. In The Prehistory of Texas, edited by T. R. Perttula, pp. 101-126. Texas A\&M Press. College Station.

Collins, M. B. and J. C. Lohse

2004 The Nature of Clovis blades and blade cores. In Entering America: Northeast Asia and Beringia before the Last Glacial Maximum, edited by D. Madsen, pp. 159-83. Salt Lake City: University of Utah Press.

Collins, M. B., D. B. Hudler, and S. L. Black

2003 Pavo Real (41BX52): A Paleoindian and Archaic Camp and Workshop on the Balcones Escarpment, South-Central Texas. Studies in Archeology 41, Texas Archaeological Research Laboratory, The 
University of Texas at Austin and Archeological Studies Program, Report 50, Environmental Affairs Division, Texas Department of Transportation.

Collins, M. B., J. C. Lohse, and M. B. Shoberg

2007 The de Graffenried Collection: A Clovis Biface Cache from the Gault Site, Central Texas. Bulletin of the Texas Archeological Society 78:101-123.

Collins, M. B., D. M. Yelacic, and C. B. Bousman

2011 "Realms," A Look at paleoclimate and Projectile Points in Texas. Bulletin of the Texas Archeological Society 82:3-30.

Collins, M. B., G.L. evens, T. N. Campbell, M. C. Winans, and C. E. Mear

1989 Clovis Occupation at Kincaid Shelter, Texas. Current Research in the Pleistocene 6:3-4.

Dering, J.P.

1989 Appendix II, Macrobotanical Remains from Soils Flotation Samples from the Bessie Kruze Site, with Thoughts about the Blackland Prairie. In Life and Death at the Bessie Kruze Site (41WM13) on the Blackland Prairie of Williamson County, by L. Johnson, pp. 213-220. Texas Department of Transportation, Environmental Affairs Division, Archeological Studies Program, Report 22.

Dillehay, T. D.

1989 Monte Verde: A Late Pleistocene Settlement in Chile-Paleoenvironment and Site Context, Vol. 1. Smithsonian Institution Press: Washington D.C.

1997 Monte Verde: A Late Pleistocene Settlement in Chile_-The Archaeological Context, Vol. 2. Smithsonian Institution Press: Washington D.C.

2000 The Settlement of the Americas. Basic Books, New York.

Dincauze, D. F.

1984 An Archaeo-Logical Evaluation of the Case for Pre-Clovis Occupations. Advances in World Archaeology 3:275-323. Academic Press, New York.

FEMA

2020 National Flood Hazard Layer. (https://www.fema.gov/national-flood-hazard-layer-nfhl). Accessed February 2020.

Gesick, J.

2000 Under the Live Oak Tree; A History of Seguin (http://www.seguintx.net/heritage/gesicktree/gesicktreeabout.html). Accessed July 13, 2015. Uploaded in 2000.

Gesick, J.

2010 "SEGUIN, TX," Handbook of Texas (http://www.tshaonline.org/handbook/online/articles/hes03), accessed July 13, 2015. Uploaded on June 15, 2010. Published by the Texas State Historical Association. 
Gould, F.W.

1975 Texas Plants: A Checklist and Ecological Summary. The Texas A\&M University Stem, Texas Agricultural Experimental Station, College Station.

Griffith, G., S. Bryce, J. Omernik, and A. Rogers

2007 Ecoregions of Texas. AS-199 (12/07) Project report to Texas Commission on Environmental Quality.

Haynes, C. V., Jr., D. J. Donahue, A. J. T. Hull, and T. H. Zabel

1984 Application of Accelerator Dating to Fluted Point Paleoindian Sites. Archaeology of Eastern North America 12:184-191.

Haynes, C. V., R.P. Beukens, A. J. T. Hull, and O.K. Davis

1992 New Radiocarbon Dates of Some Old Folsom Sites: Accelerator Technology. In Ice Age Hunters of the Rockies, edited by D.J. Stanford and J.S. Day, pp. 83-100. Denver Museum of Natural History and University Press of Colorado, Niwot.

Hofman, J. L.

1992 Recognition and Interpretation of Folsom Technological variability on the Southern Plains. In Ice Age Hunters of the Rockies, edited by D. J. Stanford and J. S. Day, pp. 193-224. Denver Museum of Natural History and University Press of Colorado, Niwot.

Hofman, J. L., L. C. Todd, C. B. Schultz, and W. Hendy

1991 The Lipscomb Bison Quarry: Continuing Investigation at ta Folsom Kill-butchery Site on the Southern Plains. Bulletin of the Texas Archeological Society 60:149-189.

Jodry, M. A. and D. J. Stanford

1992 Stewart's Cattle Guard Site: An Analysis of Bison Remains in a Folsom Kill-Butchery Campsite. In Ice Age Hunters of the Rockies, edited by D. J. Stanford and J. S. Day, pp. 101- 168. Denver Museum of Natural History and University Press of Colorado, Niwot.

Kelly, R. L., and L. C. Todd

1988 Coming into the Country: Early Paleo-Indian Hunting and Mobility. American Antiquity 53:231-244.

Kenmotsu, R.

1982 Environmental Setting. In Archeological Investigations at the San Gabriel Reservoir Districts, Central Texas, compiled and edited by T. R. Hays, pp. 3-1 to 3-23. Volume 1, Institute of Applied Sciences, North Texas State University, Denton.

Lynch, T. F.

1990 Glacial-Age Man in South America?: A Critical Review. American Antiquity 55(1):12- 36.

McAvoy, J. M. and L. D. McAvoy

1997 Archaeological Investigations of Site 44SX202, Cactus Hill, Sussex County, Virginia. Richmond; Virginia Department of Historic Resources, Research Report series, no. 8.

McGraw, A. Joachim, John W. Clark, Jr., and Elizabeth A. Robbins, editors

1998 A Texas Legacy, The Old San Antonio Road and The Caminos Reales: A Tricentennial History, 16911991. Texas Department of Transportation, Environmental Affairs Division, Austin.

Meltzer, D. J.

1989 Why Don't We Know When the First People Came to America? American Antiquity 54(3):471-490. 
Meltzer, D. J. and M. R. Bever

1995 Paleoindians of Texas: An Update on the Texas Clovis Fluted Point Survey. Bulletin of the Texas Archeological Society 66:47-81.

Meltzer, D. J., D. K. Grayson, G. Ardila, A. W. Barker, D. F. Dincauze, C. V. Haynes, F. Mena, L. Nuñez, and D. J. Stanford

1997 On the Pleistocene Antiquity of Monte Verde, Southern Chile. American Antiquity 62(4):659-663.

Prewitt, E. R.

1985 From Circleville to Toyah: Comments on Central Texas Archeology. Bulletin of the Texas Archeological Society 54:201-238.

Quigg, J. M., P. M. Matchen, C. D. Frederick, and R. A. Ricklis

2011 Root-Be-Gone (41YN452): Data Recovery of Late Archaic Components in Young County, Texas. Texas Department of Transportation, Environmental Affairs Division, Archeological Studies Program, Report No. 135 and TRC Environmental Corporation, Austin, TRC Technical Report No. 171219.

Schmidly, D.J.

1994 The Mammals of Texas, Revised Edition. University of Texas Press, Austin.

Stanford, D. J. and B. A. Bradley

2012 Across Atlantic Ice: the Origins of America's Clovis Culture. University of California Press, Berkeley.

Texas Beyond History

2008 The Gault Site. Electronic document, http://www.texasbeyondhistory.net/gault/index.html, accessed on September 12, 2014.

Texas Historical Commission

2020 Texas Archeological Sites Atlas. Electronic document. https://atlas.thc.state.tx.us/Account/Login, accessed January 2020.

Texas Water Development Board

2020 Geologic Atlas of Texas, Seguin Sheet. Electronic document, https://www.twdb.texas.gov/groundwater/aquifer/GAT/, accessed February 2020.

Tharp, B.C.

1939 The Vegetation of Texas, Academy of Science Publications in Natural History, Non-Technical Series 1.

United States Geological Survey

1964 Seguin, Texas (1994 ed.) USGS Topographic Quadrangle Map (1:24,000). Reston, VA.

USDA Natural Resources Conservation Service

2020 Web Soil Survey. Electronic document, https://websoilsurvey.sc.egov.usda.gov/App/WebSoilSurvey.aspx, accessed January 2020. 

Short Report on an Intensive Archeological Survey for the Schertz-Seguin Local Government Corporation's Proposed SH123/Austin Street Water Line Installation Project, Guadalupe County, Texas

\section{APPENDIX A}

\section{PROJECT PLANS}





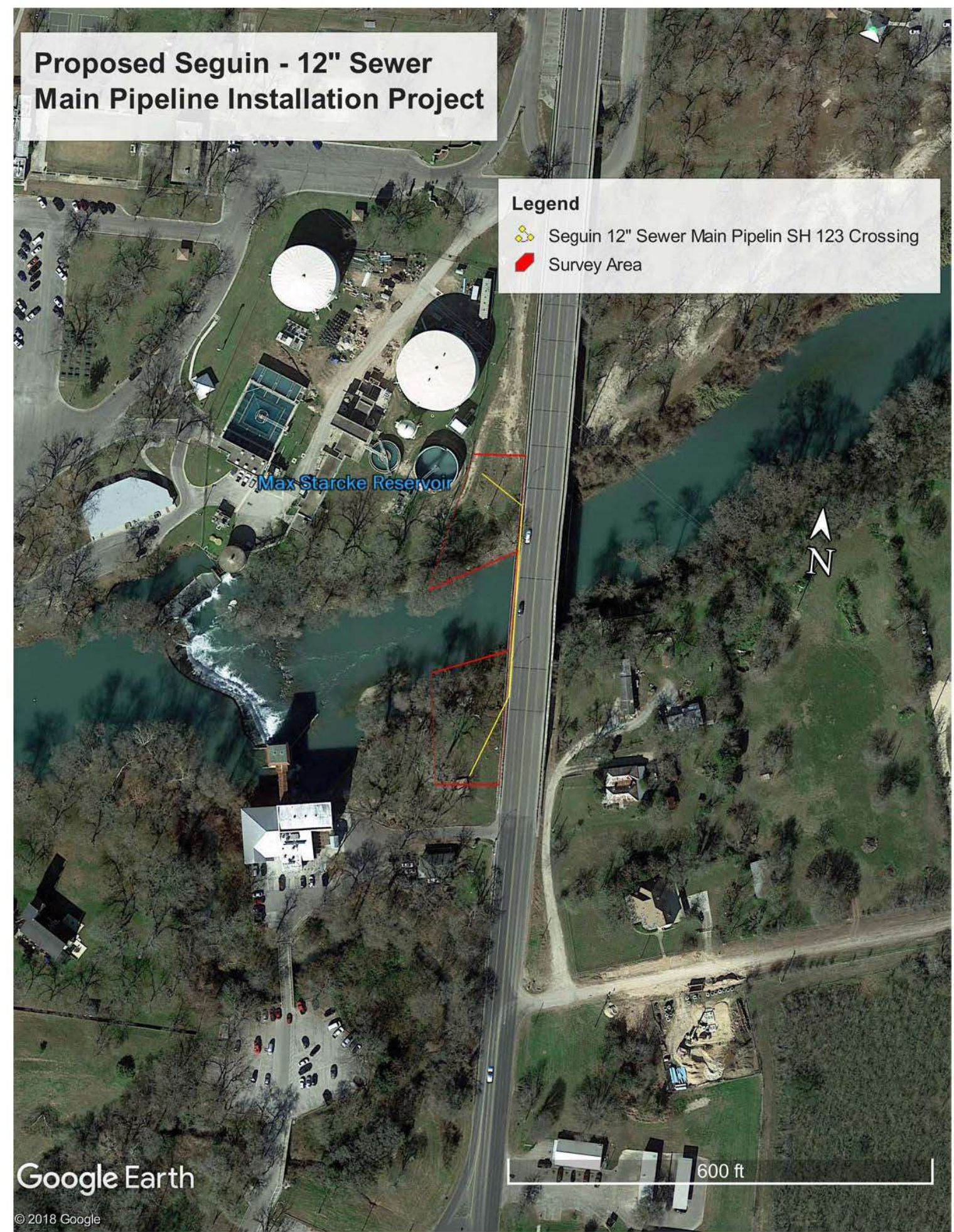



Short Report on an Intensive Archeological Survey for the Schertz-Seguin Local Government Corporation's Proposed SH123/Austin Street Water Line Installation Project, Guadalupe County, Texas

APPENDIX B

SHOVEL TEST LOG

Technical Report No. 366016.0000 



\section{1-SS, Negative}

Created

Updated

Location

Positive/Negative/No Dig

\section{GENERAL INFORMATION}

\section{Excavator}

Excavator's Initials

Date and Time

Excavation Number

Distance from previous ST (m)

State

Shovel Test ID

$\mathrm{X}$

Y

Projection Display

Field No.

SHOVEL TEST COMMENTS

\section{AREA DESCRIPTION}

Modern Land Use

Vegetation

Ground Surface Visibility

Disturbance Type

Degree of Disturbance

\section{SHOVEL TEST DATA}

2020-02-12 09:34:02 CST by Steven Sarich

2020-02-17 20:16:18 CST by Steven Sarich

$29.5521294154,-97.9695782438$

Negative

Steven Sarich

Ss

2020-02-12 09:34:02

1

Start

Texas

1-SS

599827.795468561

3269602.1196662

EPSG:32614 UTM Zone 14

N/A

$5 \mathrm{~m}$ east of water plant fence, $10 \mathrm{~m}$ north of existing water line. On a built up gravel berm. $40-50 \%$ gravel in test.

Industrial

Industrial

$10-20 \%$

Industrial

Completely Destroyed

Dig

\section{0 to 20 , neg}

ST Horizon ID

1-SS-1

Start Depth (cmbs)

0

End Depth (cmbs)

20

ST Depth

0 to 20

Soil Color

7.5YR 4/4

Soil Texture

Sandy Loam

Strat Status

Negative

Horizon Artifact Sum

0

Reason for Termination

Heavy Disturbance

Total Artifact Count

0

Shovel Test Result 


\section{SHOVEL TEST PHOTOS}

\section{General Project Overview, North}

Overview Photo ID

1-SS-1

Photos - Project Overview

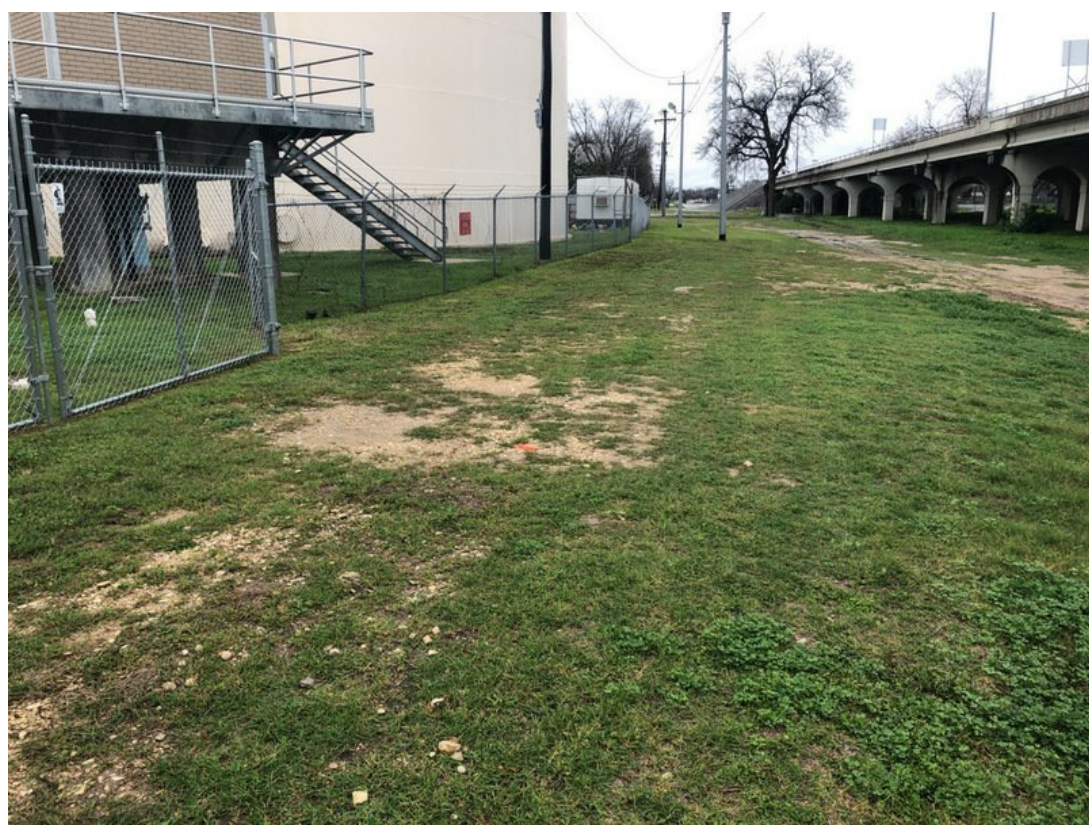

Overview Photo Direction

North

Overview Photo Type

General Project Overview

\section{General Project Overview, East}

Overview Photo ID

Photos - Project Overview

\section{1-SS-2}

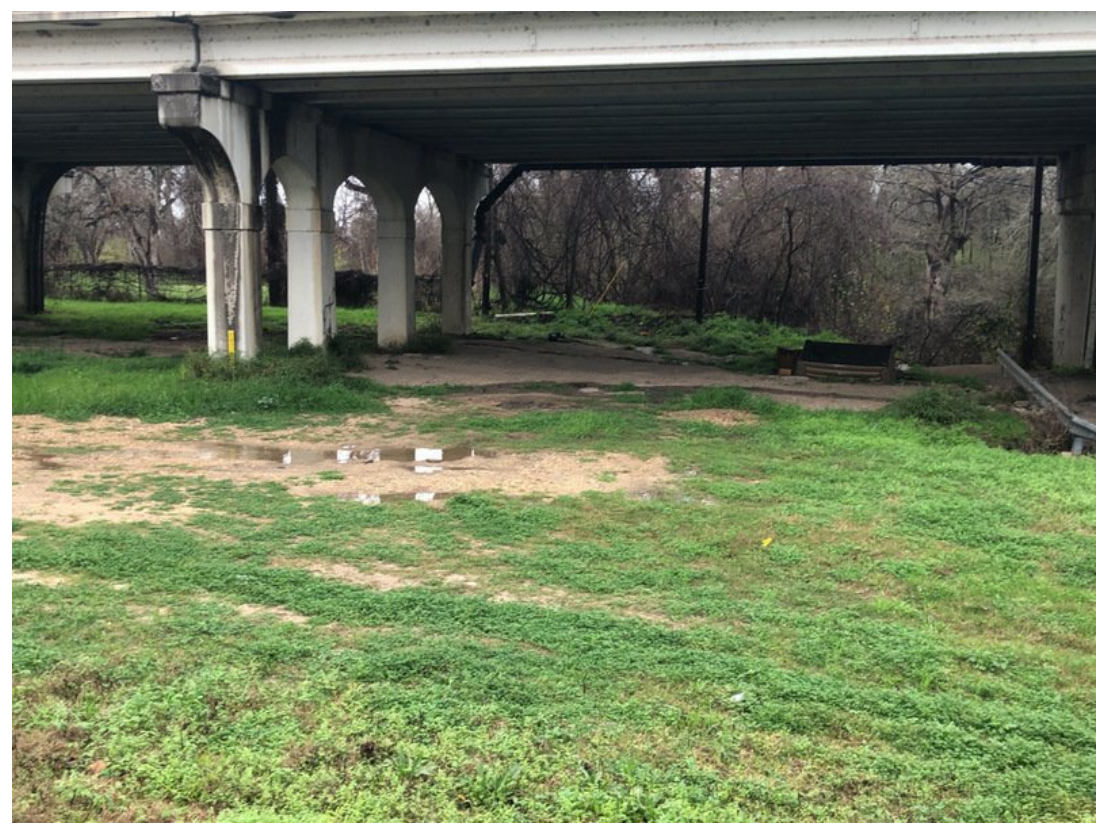

East

General Project Overview 


\section{General Project Overview, South}

Overview Photo ID

Photos - Project Overview
1-SS-3

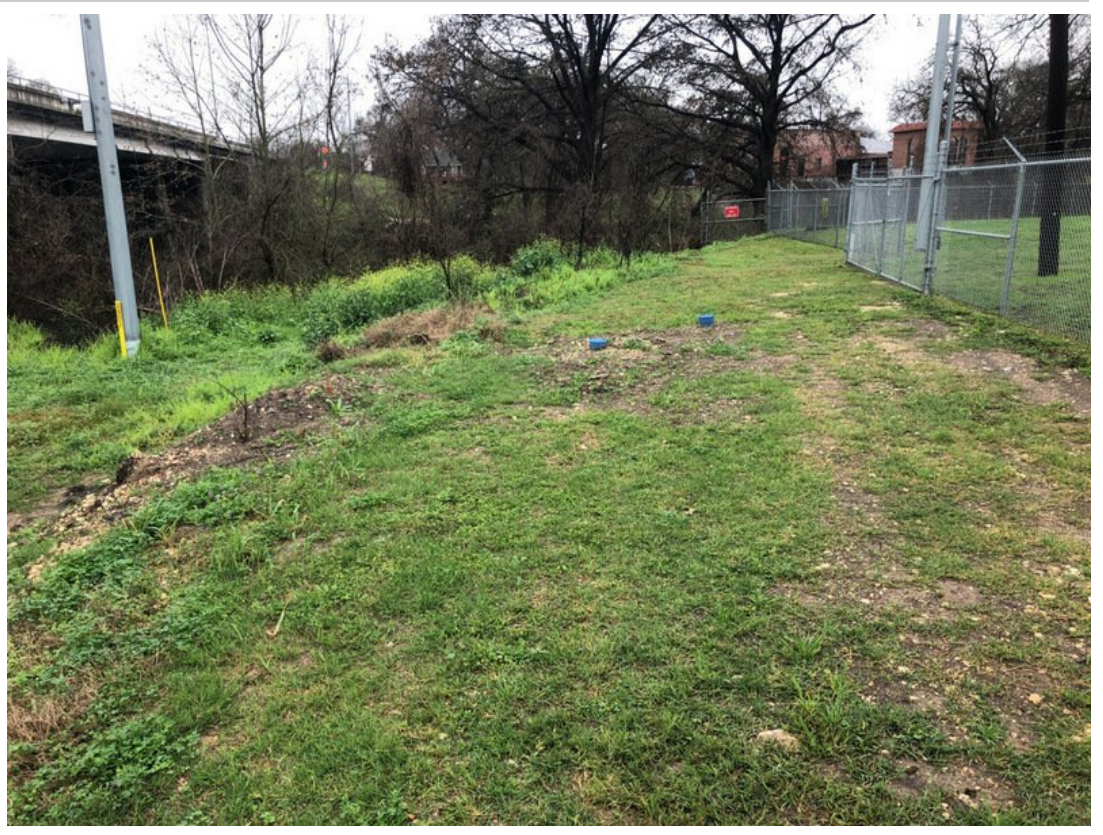

\section{South}

General Project Overview

\section{General Project Overview, West}

Overview Photo ID

Photos - Project Overview
Overview Photo Direction

Overview Photo Type
1-SS-4

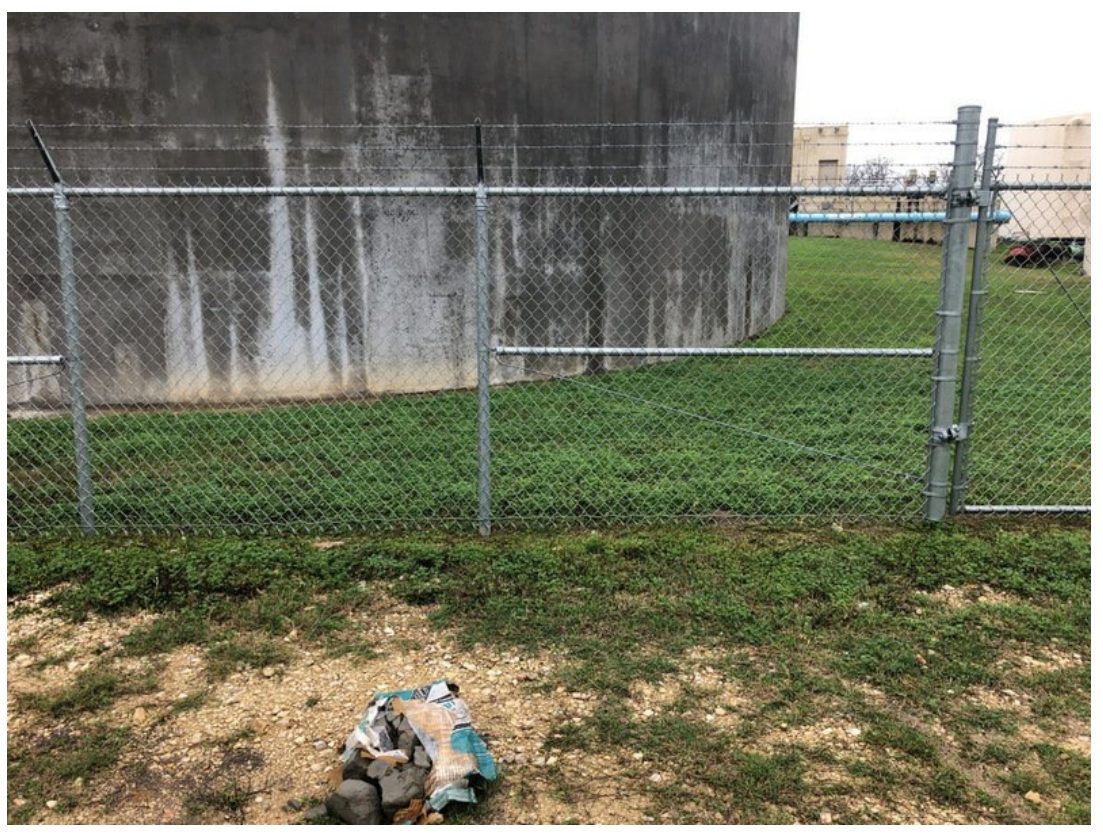

West

General Project Overview 


\section{Shovel Test, South}

ST Photo ID

1-SS-1

ST Photo

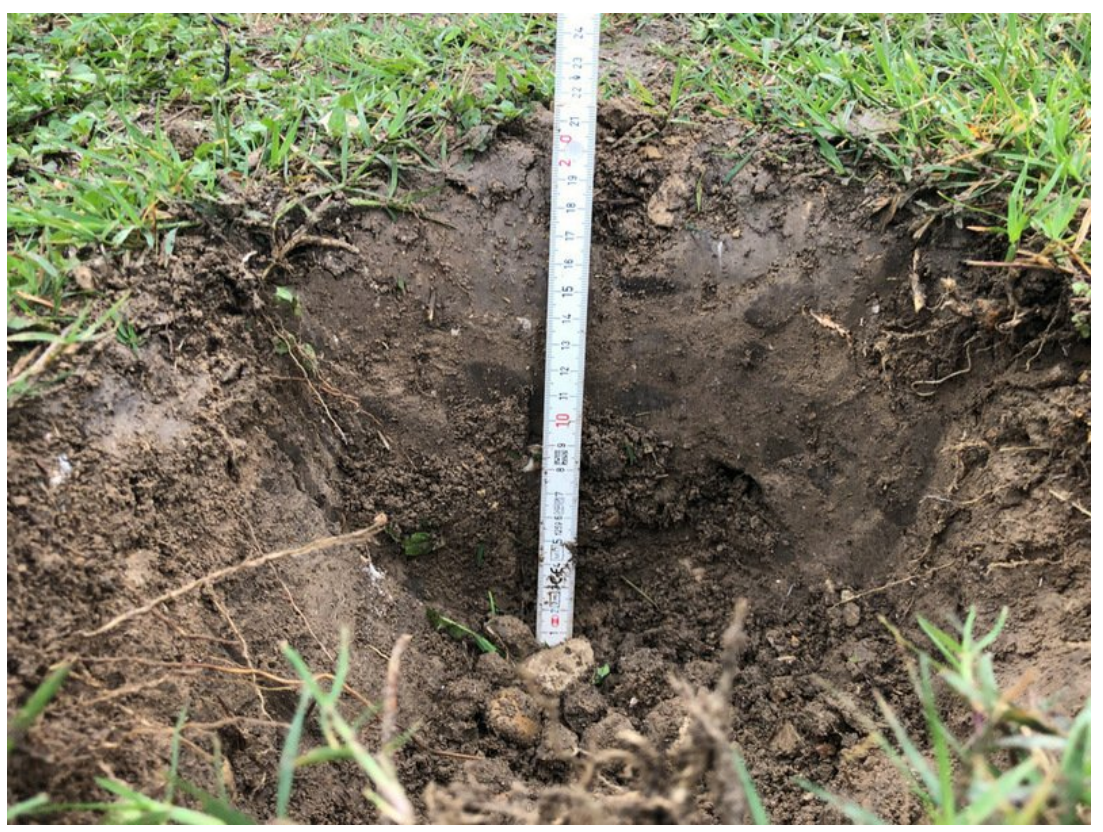

ST Photo Direction

ST Photo Type

Record URL
South

Shovel Test

https://web.fulcrumapp.com/records/d628dfc5-f4f0-4405-a1e6-1e40a8be1f52 